\title{
Silage review: Unique challenges of silages made in hot and cold regions ${ }^{1}$
}

\author{
T. F. Bernardes, ${ }^{* 2}$ J. L. P. Daniel,† A. T. Adesogan,‡ T. A. McAllister,§ P. Drouin,\# L. G. Nussio,Il P. Huhtanen, \\ G. F. Tremblay, ${ }^{* *}$ G. Bélanger, ${ }^{* *}$ and Y. Cai†† \\ *Department of Animal Science, Federal University of Lavras, Lavras, 37200000 , Brazil \\ †Department of Animal Science, State University of Maringá, Maringá, 87020900 , Brazil \\ ‡Department of Animal Sciences, Institute of Food and Agricultural Sciences, University of Florida, Gainesville 32611 \\ §Research Centre, Agriculture and Agri-Food Canada, Lethbridge, AB, Canada T1J 4B1 \\ \#Lallemand Specialties Inc., Milwaukee, WI 53218 \\ IIDepartment of Animal Science, University of São Paulo, Luiz de Queiroz College of Agriculture, Piracicaba, 13418900, Brazil \\ TDepartment of Agricultural Research for Northern Sweden, Swedish University of Agricultural Sciences, Umea, S-90183, Sweden \\ ${ }^{* \star}$ Agriculture and Agri-Food Canada, Quebec Research and Development Centre, Québec, QC, Canada, G1V 2J3 \\ ††National Institute of Livestock and Grassland Science, Tsukuba, Ibaraki, 305-0901, Japan
}

\section{ABSTRACT}

Silage making can be conveniently divided into field, ensiling, storage, and feed-out phases. In all of these stages, controllable and uncontrollable components can affect silage quality. For instance, silages produced in hot or cold regions are strongly influenced by uncontrollable climate-related factors. In hot regions, crops for silage are influenced by (1) high temperatures negatively affecting corn yield (whole-crop and grain) and nutritive value, (2) butyric and alcoholic fermentations in warm-season grasses (Panicum, Brachiaria, and Pennisetum genera) and sugarcane, respectively, and (3) accelerated aerobic deterioration of silages. Ensiling expertise and economic factors that limit mechanization also impair silage production and utilization in hot environments. In cold regions, a short and cool growing season often limits the use of crops sensitive to cool temperature, such as corn. The fermentation triggered by epiphytic and inoculated microorganisms can also be functionally impaired at lower temperature. Although the use of silage inoculants has increased in Northern Europe, acid-based additives are still a good option in difficult weather conditions to ensure good fermentation quality, nutritive value, and high intake potential of silages. Acid-based additives have enhanced the quality of round bale silage, which has become a common method of forage preservation in Northern Europe. Although all abiotic factors can affect silage quality,

Received August 18, 2017.

Accepted October 5, 2017.

${ }^{1}$ This article is part of a special issue on silage management.

${ }^{2}$ Corresponding author: thiagobernardes@dzo.ufla.br the ambient temperature is a factor that influences all stages of silage making from production in the field to utilization at the feed bunk. This review identifies challenges and obstacles to producing silages under hot and cold conditions and discusses strategies for addressing these challenges.

Key words: silage problem, silage production, temperate crop, tropical crop

\section{INTRODUCTION}

Silage making is an old agricultural practice that started more than 3,000 yr ago (Wilkinson et al., 2003). However, a rapid increase in the application of this technology occurred after the 1940s as a result of the mechanization of forage harvesting (Wilkinson et al., 2003). Silage making is well established in the temperate regions of North America and Europe but has only recently become popular and widespread in tropical regions (Wilkins and Wilkinson, 2015).

Production of high-quality silage is dependent on both controllable and uncontrollable factors. Silage management factors that are under the control of the farmer are forage species and agricultural background, stage of maturity or moisture concentration at harvest, harvesting and ensiling methods, type of storage structure, use of silage additives, feed-out methods, feed bunk management, and diet formulation (Mahanna and Chase, 2003). Uncontrollable climate-related factors that are common or specific to warm or cold regions can adversely affect silage production and utilization and can influence some of the factors listed above, such as moisture concentration at harvest. The objective of this article is to identify challenges and obstacles to producing silages under hot and cold conditions and to discuss strategies for addressing these challenges. 


\section{SILAGE MAKING IN HOT AREAS}

\section{Effects of High Temperature on the Yield and Attributes of Crops and Silages}

The concentration and digestibility of NDF are by far the most important variables related to forage nutritive value. However, in ensiled forages, the nutritive value is further affected by the fermentation pattern (extent and profile), which in turn can influence DMI (Huhtanen et al., 2007). The prevailing climate can exert considerable effects on the DM yield and quality of silages, and in some instances these effects may surpass the effect of maturity at harvest on the ensiling process.

Corn and Sorghum. Relatively few studies have focused on the effects of temperature on the yield of whole corn plants. For instance, Struik (1983) reported that high temperatures accelerated kernel development and leaf senescence, reducing kernel viability and final plant yield. Effects of temperature alone on crop yields are typically determined via modeling to avoid the confounding effects of several other factors such as the location, soil type, nutrient status, management, and other climatic attributes. Most of the existing research has focused on corn kernel yields rather than yields of the whole plant. Muchow et al. (1990) used modeling to demonstrate the inverse relationship between increasing temperatures and corn grain yield in the following cities: Gainesville, Florida; Katherine, Australia; Quincy, Florida; Champaign, Illinois; and Grand Junction, Colorado. They highlighted the importance of the length of the grain-filling period in determining the yield because the DM in the grain is largely accumulated after flowering and is typically inversely related to increasing temperature. Schlenker and Roberts (2006) reported that corn yields decreased in a nonlinear manner with temperatures above $25^{\circ} \mathrm{C}$, but even short periods above $30^{\circ} \mathrm{C}$ caused considerable yield losses. Likewise, based on climate and yield data spanning most US counties from 1950 to 2005, Schlenker and Roberts (2009) reported that the yield of corn grain gradually increased up to $29^{\circ} \mathrm{C}$, but temperatures above this threshold markedly reduced yields. They noted that the slope of the decline above the optimum value of $29^{\circ} \mathrm{C}$ is much steeper than the incline below it. In addition, Bassu et al. (2014) evaluated 23 models for corn growth at 4 locations representing a wide range of corn production conditions around the world (Ames, Iowa; Lusignan, France; Morogoro, Tanzania; and Verde, Brazil). Several models indicated that temperature increases above $30^{\circ} \mathrm{C}$ reduced grain yield by $0.5 \mathrm{t} / \mathrm{ha}$ per Celsius degree.

Corn silage is the most energy dense forage source used in dairy cow diets in tropical environments (Bernardes and Rêgo, 2014; De Oliveira et al., 2017). How- ever, corn silage from hot or tropical regions is usually poorer in quality compared with corn silage produced in cool or temperate climates. Adesogan (2010) reviewed the chemical composition of 3,070 corn silage samples from Florida and New York analyzed at the Dairy One Forage Laboratory (Ithaca, NY) over a 5-yr period (2004-2009). Florida corn silages consistently had lower concentrations of starch and greater concentrations of acid detergent-insoluble CP (ADICP), $\mathrm{NDF}, \mathrm{ADF}$, and lignin. The greater cell wall and ADICP concentrations in the Florida silages may be attributable to the effects of higher temperatures on cell wall deposition, although this cannot be verified because the data were not from a controlled experiment. Nevertheless, several authors have reported that high temperatures increase fiber or lignin deposition (Wilson et al., 1991; Moore and Jung, 2001). This is partly because higher temperatures increase the rate of plant development (Buxton, 1996) and the activity of lignin synthetic enzymes (Buxton and Fales, 1994). These responses increase the partitioning of DM to more lignified tissues, such as the shoots (Hardacre and Turnbull, 1986; Cone and Engels, 1990; Moore and Jung, 2001). The higher ADICP concentration in the Florida versus New York silages sampled by Adesogan (2010) is consistent with the effects of higher temperatures in the study of Garcia et al. (1989). Likewise, Kim and Adesogan (2006) reported that a higher ensiling temperature ( 40 vs. $20^{\circ} \mathrm{C}$ ) increased the concentration of ADICP or heat-damaged proteins in corn silage. Reactions between sugars and amino groups form the ADICP through the Maillard reaction, which occurs at $>40^{\circ} \mathrm{C}$ in silages (Muck et al., 2003). The rate of the reaction also increases exponentially with temperature (Goering et al., 1973). Heat-damaged proteins formed in the Maillard reaction are usually indigestible in vivo; therefore, elevated temperatures can reduce the feed value of protein in corn silage.

Logically, lower grain yields at higher temperatures also result in lower starch concentration in corn silage due to the influence of temperature on starch synthase, the enzyme controlling starch synthesis in the grain. Keeling et al. (1994) reported that temperatures above $30^{\circ} \mathrm{C}$ irreversibly inactivate starch synthase, precluding the deposition of starch in the kernel. However, a study conducted in Brazil found that corn silage produced on intensive dairy farms located in the south and southeast had satisfactory starch concentration (De Oliveira et al., 2017), as shown in Figure 1.

Corn silage digestibility is usually decreased at high temperatures due to the reduction in starch concentration and increase in lignin and fiber deposition in the plant. Cone and Engels (1990) reported that corn grown at higher temperatures $\left(12 \mathrm{~h}\right.$ at $30^{\circ} \mathrm{C}$ and $12 \mathrm{~h}$ 
at $24^{\circ} \mathrm{C}$ ) exhibited decreased cell wall thickness, cell diameter, and cell wall yield but had double the lignin content, resulting in a decrease in in vitro digestibility compared with corn grown at low temperature $(12 \mathrm{~h}$ at $18^{\circ} \mathrm{C}$ and $12 \mathrm{~h}$ at $12^{\circ} \mathrm{C}$ ). Crasta and Cox (1996) also reported that growing corn at a warmer location reduced in vitro DM digestibility relative to growing it at a cool location. Adesogan (2010) reported that Florida corn silages consistently had lower total digestible nutrient concentrations compared with New York corn silages, but NDF digestibility (NDFD) values did not consistently differ.

Corn hybrids grown in Brazil predominantly have flint kernels and the associated greater proportion of vitreous endosperm. Although kernel processing improves starch availability (Ferraretto and Shaver, 2012), many farmers in tropical regions do not have ac-

(A)

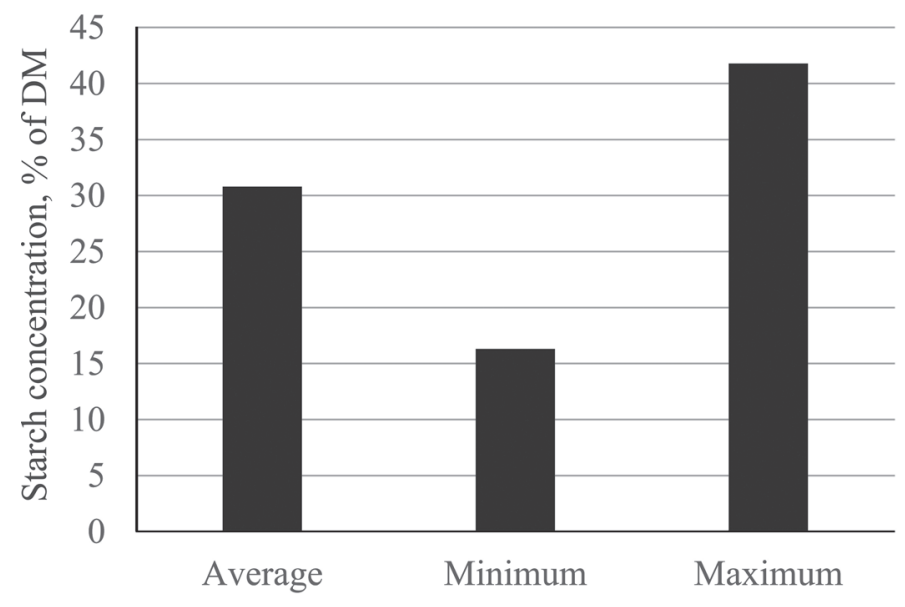

(B)

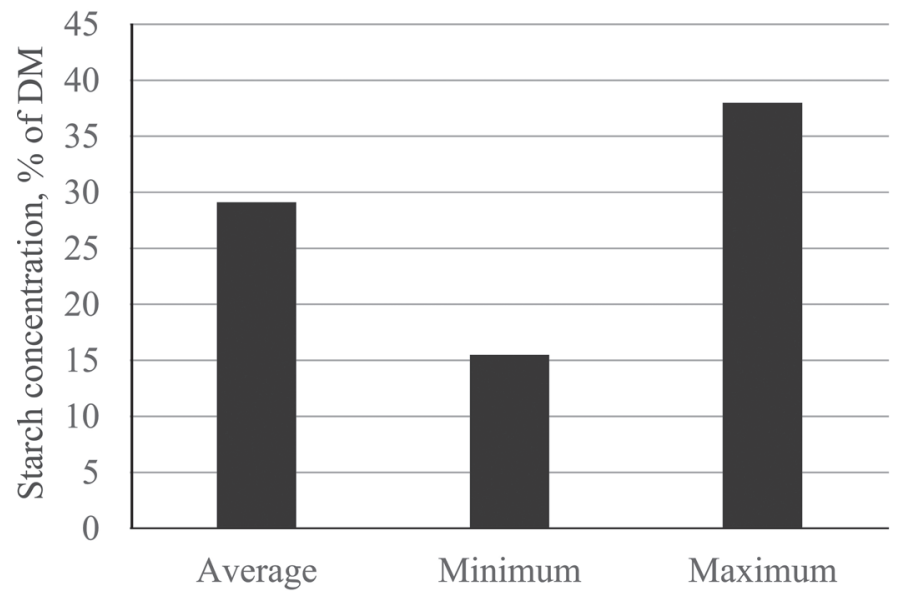

Figure 1. Starch concentrations of tropical corn silages from the central core (A) and the top (B) of the silos. Data from De Oliveira et al. (2017). cess to kernel processors. For instance, in Brazil farmers use pull-type harvesters without kernel processors (Bernardes and Rêgo, 2014). When corn is ensiled, the rate of starch digestion increases as the length of storage time increases (Macken et al., 2003; Benton et al., 2005; Carvalho et al., 2017). Because of this, several beef and dairy farmers in Brazil have adopted highmoisture corn silage, reconstituted corn grain silage (Carvalho et al., 2017), and ear corn silage (snaplage) as feed sources. Fernandes (2014) ensiled flint and dent corn grains harvested at different maturities. Although vitreousness and maturity affected starch digestibility before ensiling, no differences were observed in starch digestibility after $60 \mathrm{~d}$ of storage. In fact, Correa et al. (2003) did not observe any differences in starch digestibility, DMI, or milk yield in dairy cows fed diets containing flint versus dent corn silages. Thus, vitreousness of grain remains important for selection of grain types to be rolled and ground and fed as dry corn grain, but not for silages (Owens, 2008). Considering that both starch and NDF are the major nutrients in corn silage and that starch digestibility typically increases during ensiling (Daniel et al., 2015), NDFD is the principal nutritional trait used for selecting corn hybrids for silage production (Lopes et al., 2009; Zopollato and Sarturi, 2009; De Oliveira et al., 2017).

Higher ensiling temperatures typically lead to a shift from a homolactic to a heterolactic microbial population. Zhou et al. (2016) examined the influence of ensiling temperature $\left(5,10,15,20\right.$, and $\left.25^{\circ} \mathrm{C}\right)$ on fermentation characteristics and microbial counts of corn silage. A 10-fold increase in lactic acid bacteria (LAB) counts was detected after $28 \mathrm{~d}$ of ensiling at 25 versus $5^{\circ} \mathrm{C}$. Furthermore, at the higher ensiling temperatures (15$25^{\circ} \mathrm{C}$ ), shifts from homolactic to heterolactic bacteria occurred, whereas the homolactic bacterium Lactobacillus sakei dominated the fermentation at 5 and $10^{\circ} \mathrm{C}$. Due to such shifts in the microbial population, corn silages produced in warm climates or at higher temperatures typically exhibit a more heterolactic fermentation as evidenced by greater acetate concentrations and lower lactate concentrations (Kim and Adesogan, 2006; Adesogan, 2010; Wang and Nishino, 2013; Weiss et al., 2016). Zhou et al. (2016) reported that silages incubated at higher temperatures $\left(15-25^{\circ} \mathrm{C}\right)$ had higher levels of acetic acid and a higher acidification rate than those incubated at lower temperatures $\left(5\right.$ and $\left.10^{\circ} \mathrm{C}\right)$. In addition, ensiling at the 2 highest temperatures (20 and $25^{\circ} \mathrm{C}$ ) eliminated the lag time before the $\mathrm{pH}$ declined, whereas lag times for the lower ensiling temperatures were 2 to $3 \mathrm{~d}$.

Heterolactic fermentations often lead to higher DM losses during ensiling (McDonald et al., 1991) but are usually associated with improved aerobic stability 
(Driehuis et al., 1999) because of greater concentrations of antifungal compounds such as acetate. Nonetheless, under hot or tropical conditions, silages are more prone to aerobic spoilage (Ashbell et al., 2002; Adesogan, 2009) and may still benefit from additives that improve aerobic stability, such as weak acids (e.g., benzoate and sorbate; Da Silva et al., 2014; Bernardes et al., 2015) and heterolactic inoculants (e.g., Lactobacillus buchneri; Queiroz et al., 2013). This is because high temperatures are often more conducive for the growth of spoilage organisms, and the levels of naturally produced antifungal fermentation products are often insufficient to curtail their growth. For example, Koc et al. (2009) examined the aerobic stability of silages at room temperature $\left(20^{\circ} \mathrm{C}\right)$ or elevated temperatures $\left(30-37^{\circ} \mathrm{C}\right)$. The highest yeast and mold counts and $\mathrm{CO}_{2}$ production occurred at the higher temperatures. Likewise, when corn and wheat silages were exposed to air at 10, 20, 30, and $40^{\circ} \mathrm{C}$, the highest yeast and mold counts and greatest deterioration occurred at $30^{\circ} \mathrm{C}$ (Ashbell et al., 2002). However, Weinberg et al. (2001) reported that aerobic stability of corn and wheat silages was greater at a higher $\left(37-41^{\circ} \mathrm{C}\right)$ versus a lower $\left(33^{\circ} \mathrm{C}\right)$ temperature.

Sorghum is an annual crop that is well adapted to environments with limited rainfall and high temperatures (Mann et al., 1983), but sorghum silage typically has a lower nutritive value than corn silage (Pino and Heinrichs, 2017). In Brazil, seed companies have focused on taller varieties with high DM yield and low grain:forage ratio. Additionally, a higher percentage of grains can pass undigested through the animal with sorghum silage compared with corn silage (Martin and Peel, 2013). Another challenge with sorghum crop is bird damage during grain ripening (Duncan, 1980). Therefore, sorghum has been adopted as an alternative to corn for the second crop or even for the summer crop in areas susceptible to drought. Dual-purpose varieties seem to have a more favorable grain:stover ratio and DM yield and avoid lodging.

Tropical Grasses. Beyond corn and sorghum silages, tropical grass silages are important forages in warm climates. Warm-season grasses often have a higher moisture content at harvest than cereal crops. Therefore, harvest timing is critical, and wilting or application of additives is often needed to reduce the risk of a butyric fermentation and effluent production (Nussio, 2005). Besides the high moisture, the low concentration of water-soluble carbohydrate (WSC) can impair the ensiling of some warm-season grasses. Pholsen et al. (2016) found lower LAB numbers and WSC concentration in Guinea grass (Panicum maximum) compared with Napier grass (Pennisetum purpureum). Guinea grass silages were poorer in quality due to lower $\mathrm{DM}$ and lactic acid concentrations and higher $\mathrm{pH}$ and ammonia nitrogen concentrations. In addition, the $\mathrm{pH}$ of Guinea grass silage failed to decline below 4.0, allowing a clostridial fermentation that resulted in increased butyric acid and ammonia nitrogen production.

Although wilting is a feasible strategy to decrease moisture content in short and thin-stemmed crops, several species of warm-season grasses used for silage are tall and have thick stems (e.g., Panicum maximum, Pennisetum purpureum) and are consequently difficult to wilt. Therefore, ensiling tropical grasses with absorbents can produce silages with higher intake potential and improved DM digestibility depending on the additive selected (Bernardes et al., 2005). Hence, in smallscale silage production, dry by-products (e.g., soybean hulls, citrus pulp, cassava pulp, wheat bran, rice bran, corn gluten feed), energetic meals (e.g., corn meal, sorghum meal, pearl millet meal), or even protein meals (e.g., cottonseed meal, peanut meal, sunflower meal) have been used as absorbents during the ensiling of tropical grasses (Gusmão et al., 2017). Coffee hulls, rice hulls, and cotton hulls have also been examined, but the low digestibility and the presence of antinutritional factors in these absorbents often produces low-quality silage even with optimal moisture levels (Carvalho et al., 2007).

Sugarcane. Sugarcane is a competitive tropical forage source due to its high DM yield (e.g., 40-50 t of DM/ ha) and suitable nutritive value at maturity (Daniel et al., 2017). Although sugarcane is often harvested and fed daily during periods of pasture shortage, it is also ensiled to avoid later lodging, reduce the risk of loss by fire, and avoid the need for daily harvesting (Pedroso et al., 2008). As sugarcane is a semiperennial tropical grass, its field life span may be prolonged by uniform harvesting and postharvest management. However, due to its high content of soluble carbohydrates and large yeast population (Ávila et al., 2010), ensiling sugarcane results in the conversion of part of the soluble sugars into high levels of volatile organic compounds, principally ethanol (Daniel et al., 2013c). For many years, farmers and technicians claimed that ethanol depressed DMI. To date, considerable evidence indicates that ethanol does not impair feed intake (Ham et al., 1994; Randby et al., 1999; Raun and Kristensen, 2011; Daniel et al., 2013a) and actually is a valuable energy source. However, because ethanol is volatilized from the silo face during diet mixing and in the feed bunk (Daniel et al., 2013a), considerable amounts of net energy are lost when sugarcane is conserved by natural fermentation. Although ethanol (7.1 Mcal $/ \mathrm{kg})$ has a higher content of gross energy than carbohydrates (4.2 Mcal/ $\mathrm{kg}$ ), replacing dietary carbohydrates with ethanol has led to similar or even lower feed efficiency (Ham et al., 1994; Randby et al., 1999; Daniel et al., 2013a). Hence, 
ethanol fermentation is still undesirable. Application of effective additives to sugarcane at ensiling (e.g., sodium benzoate, L. buchneri) conserves most soluble carbohydrates, and its nutritive value is comparable with freshly chopped sugarcane (Queiroz et al., 2008).

Sugarcane silage comprises 3 main fractions: soluble carbohydrates (mainly sucrose), fermentation end products, and NDF; crude protein, ether extract, and ash compose less than $7 \%$ of sugarcane silage DM. The true digestibility of the soluble fraction (soluble carbohydrates + fermentation end products) is almost 100\%; therefore, the nutritive value of sugarcane is primarily a function of the concentration and digestibility of NDF. The concentration of NDF is dependent on crop maturity, genotype, soil fertility, and use of effective silage additives, which ultimately affects the recovery of soluble sugars and, by dilution, the NDF concentration. Compared with temperate grasses, sugarcane NDFD is typically low ( $<35 \%$; Oliveira et al., 2011) due to the higher proportion of indigestible NDF ( $\sim 50 \%$ of NDF) and lower digestibility of potentially digestible NDF (Daniel et al., 2013b). Compared with other grasses and legumes, sugarcane presents a low content of lignin in NDF. However, the negative effect of lignin on sugarcane fiber digestibility is even more pronounced than in other grasses (Daniel et al., 2017). The low nanoporosity of the sugarcane cell wall, especially for regions with higher lignification, is a major determinant of sugarcane cell wall recalcitrance (Maziero et al., 2013). Additionally, the arrangement of lignified tissues in C4 grass stems, such as the formation of a sclerenchyma ring in the stem cortex zone, further hinders particle breakdown (Wilson, 1993). These properties increase ruminal retention time and physical fill, accounting for the higher physical effectiveness of sugarcane NDF (Goulart et al., 2009; Sá Neto et al., 2014) and the lower DMI of sugarcane-based diets (Correa et al., 2003; Oliveira et al., 2011) compared with temperate forage-based diets (e.g., corn silage).

Two strategies have been used to overcome the low NDFD of sugarcane silage. Chopping sugarcane into fine particles benefits the packing and preservation of silage and decreases the sorting that can result in nutrient imbalances and digestive disturbances. Moreover, sugarcane NDF retains its high physical effectiveness even when it has a short particle length (Campos, 2015). Santos (2010) reported a linear increase in milk yield without alteration in milk fat content in crossbred Holstein-Jersey cows fed sugarcane with an increasingly reduced particle size. Hypothetically, finely chopped particles increased the ruminal turnover and lowered the constraints that rumen fill exerted on feed intake (Gherardi et al., 1992).
Another strategy for improving the nutritive value of sugarcane silage-based rations is to increase the dietary proportion of concentrates (Costa et al., 2005). Sá Neto et al. (2014) demonstrated that formulating dairy rations with an equal physically effective NDF resulted in similar production performance when sugarcane was substituted for corn in the diets of dairy cows. Reported values of the physical effectiveness factor of sugarcane NDF are around $20 \%$ higher than those of corn silage NDF (Goulart et al., 2009; Sá Neto et al., 2014).

Considering its high physical effectiveness, sugarcane silage is a very attractive forage source for beef feedlots because a low dietary inclusion is enough to meet physically effective fiber requirements. Additionally, silage moisture assists in bunk management, reducing dust and fines and improving the ration texture compared with dry roughages (e.g., hay). Hence, a very high stocking rate is feasible in feed yards that use sugarcane silage-based diets.

\section{Aerobic Deterioration of Silages-An Important Issue in Hot Climates}

Aerobic microorganisms are by far the greatest single source of losses in silage making (Woolford, 1990). The aerobic deterioration of silage causes DM and nutrients losses (McDonald et al., 1991). When offered to ruminants, spoiled silage is often partially or completely refused (Gerlach et al., 2013), and if consumed it can affect metabolic parameters and immunity (Korosteleva et al., 2007). Furthermore, aerobic deterioration of silage can cause problems for humans due to transfer of pathogens and mycotoxins from the silage to other feeds and animal products such as milk (Ogunade et al., 2016).

Aerobic microorganisms initiate their activities in the field and when the silo is being filled; however, the process of aerobic deterioration becomes more pronounced during storage and the feed-out phases (Honig, 1991). Even during storage, tropical environments can have adverse effects on the physical properties of plastic films used to cover silos. In particular, tropical climatic conditions reduce air-tightness and resistance of the film to radiation and high temperatures (Paillat and Gaillard, 2001). Thus, in warm climates, plastic films can readily become more permeable to air, especially if they are used to cover silages for long storage periods.

At the time of unloading, high temperatures can increase the growth rates of spoilage microbes, leading to increased silage deterioration. Ashbell et al. (2002) exposed corn and wheat silages to air for 3 or $6 \mathrm{~d}$ at $10,20,30$, and $40^{\circ} \mathrm{C}$. The greatest deterioration occurred at $30^{\circ} \mathrm{C}$ due to greater growth of yeasts at this 
temperature. McDonald et al. (1991) also noted that the temperature range of yeasts is very variable, with growth occurring from 5 to $50^{\circ} \mathrm{C}$ and optimum growth of most species occurring at $30^{\circ} \mathrm{C}$. These authors also noted that the optimal temperature for spoilage molds and clostridia was between 25 and $35^{\circ} \mathrm{C}$ and $37^{\circ} \mathrm{C}$, respectively. Bonner and Fergus (1960) studied the effects of 3 temperatures and 6 relative humidities on the growth and survival of 10 fungi isolated from silage. They discovered that no growth occurred at $50^{\circ} \mathrm{C}$, but all fungi grew at 25 and $37^{\circ} \mathrm{C}$ when the relative humidity exceeded $85 \%$. Fungal growth was optimized at a relative humidity of $100 \%$ and $25^{\circ} \mathrm{C}$. Therefore, warm, moist climates are more likely to increase the growth of spoilage fungi and accelerate silage deterioration.

\section{Preventing Aerobic Deterioration}

Once silage begins to deteriorate due to aerobic exposure, little can be done to curtail the process. Consequently, preventing silage spoilage is key, and efforts toward this goal should be directed before, during, and after ensiling. Management practices that can be used to prevent aerobic spoilage before ensiling include harvesting forages at the correct DM concentration and particle size. These factors are critical to optimize the packing density and minimize silage porosity, factors that predispose silage to spoilage. The ideal DM concentration and particle size are crop specific. Additional management strategies for preventing aerobic deterioration include packing forages into the silo at an ideal rate and density, using silage additives to reduce aerobic spoilage, and choosing the type of plastic cover and daily feed-out rate and method that minimize spoilage. Each of these factors is discussed below with a focus on warm climates.

Packing and Filling. The recommended minimum pack density of silages is $705 \mathrm{~kg} / \mathrm{m}^{3}$ (as-fed basis) with a porosity of less than 0.4 (Holmes, 2009). However, density is usually lower in the top layers than in the center layers of bunker and stack silos (D'Amours and Savoie, 2005). Borreani et al. (2008) reported bulk densities in the peripheral areas (top center and top lateral; $0.50 \mathrm{~m}$ from the top) of bunker silos and stacks of corn silage on 62 commercial farms to be in the range of 133 to 487 and 141 to $428 \mathrm{~kg} / \mathrm{m}^{3}$ for bunkers and stacks, respectively. Corresponding bulk densities at the cores of the surveyed silos were 578 and $593 \mathrm{~kg} /$ $\mathrm{m}^{3}$, respectively. The lower values observed in the peripheral areas were found on farms where bunker silos were overfilled, with the silage mass extending above the walls of the silo. Researchers in Brazil also observed that overfilled bunker silos had lower silage densities and greater yeast counts in the top layers of the bunker (T. F. Bernardes, I. L. De Oliveira, and L. M. Lima, Department of Animal Science, Federal University of Lavras, Brazil; unpublished data). These observations highlight the importance of taking particular care to fill bunker silos in a manner that ensures adequate packing density and oxygen exclusion.

Producers achieving high packing densities use tractors with weights and tire widths that promote a high degree of compaction and pack the silage in shallow $(<0.15 \mathrm{~m})$ layers. When the delivery rate to the silo is high (as when harvesting with self-propelled harvesters), one or more additional packing tractors are needed. In a well-packed silo, all tractor tires will pass over the entire packing layer surface at least once, with more passes being beneficial (Muck and Holmes, 2000). Because density near the wall of a bunker silo is frequently lower than that toward the center, packers should make additional passes near the walls.

Silage Additives. In warm climates, cereal silages are even more likely to deteriorate because aerobic yeasts are more active at high temperatures. Several chemical additives can reduce aerobic spoilage; some of the most effective include potassium sorbate and sodium benzoate. A study evaluated 2 potassium sorbate and sodium benzoate application rates in improving the aerobic stability of corn silage (Bernardes et al., 2015). Both additives applied at $2 \mathrm{~g} / \mathrm{kg}$ effectively reduced silage spoilage compared with untreated corn silage. Because the high cost of the chemical additive can limit its application to the entire silage mass, it may be applied only to the surface of the silage, where the risk of deterioration is greatest (Da Silva et al., 2014).

With respect to microbial inoculants, several studies have shown that inoculants containing L. buchneri alone or a combination of L. buchneri and homolactic acid bacteria can improve the aerobic stability of silages. For instance, Queiroz et al. (2012) showed that an inoculant containing L. buchneri and Pediococcus pentosaceus reduced the amount of spoilage in 3.6-mwide bags by more than 50\%. Mari et al. (2009) also showed that application of the same inoculant reduced yeast counts and increased the aerobic stability of corn silages on several commercial farms.

Sealing. A plastic film to cover silage has to fulfill 3 essential functions. The film should prevent precipitation and damage caused by rain, hail, or birds. It should be UV resistant to remain intact after prolonged exposure to sunlight. Finally, it must ensure anaerobic conditions during ensiling (Bernardes, 2016). Besides having a high-quality plastic, the nature of how the film covers the forage is important. Recently, studies were undertaken to examine the use of oxygen barrier film 


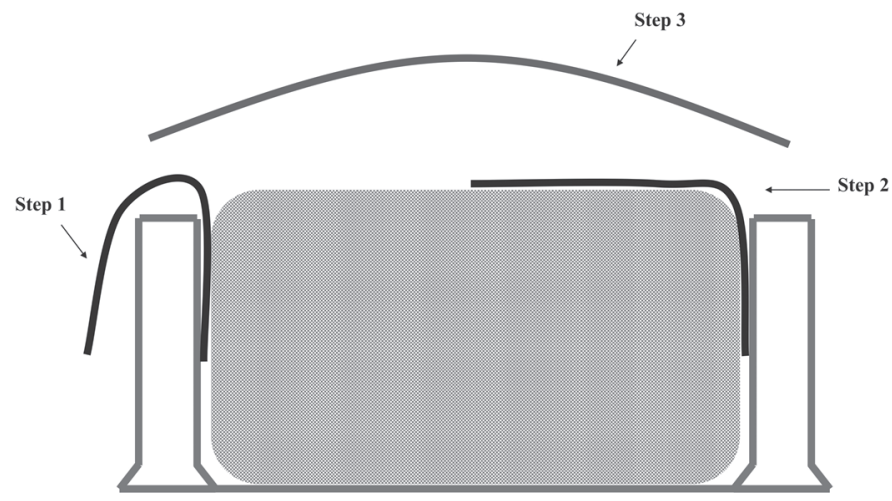

Figure 2. Bunker lining diagram. Step 1: before silo filling, place a plastic sheet along the length of the sidewall with approximately 2 $\mathrm{m}$ of excess draped over the wall. Step 2: sidewall plastic should overlap onto the forage top at the end of filling. Step 3: cover the bunker with additional plastic film. (C) 2016 T. F. Bernardes. Published in Bernardes (2016) under a CC BY 3.0 license. Available from https:// doi.org/10.5772/65445.

on the walls and top regions of bunker silos compared with only a single layer of standard polyethylene film on top of the bunker (Lima et al., 2017). With the oxygen barrier film, silage next to the bunker wall exhibited a quality that was similar to that in the central core and superior to that in bunkers that were sealed only with a top film (Borreani and Tabacco, 2014). Lining the inside of bunker walls before filling is an alternative approach to ensuring more complete exclusion of oxygen during ensiling and storage (Bernardes, 2016; Figure 2). Thus, using high-quality plastic film and ensuring close contact of the film with the silage surface are essential for the production of high-quality tropical silages (Lima et al., 2017).

Weighting the Plastic Cover. Borreani and Tabacco (2007) presented the results of a study on different silage sealing systems. A farm bunker silo was covered with a single black-on-white sheet. Half of the width of the sheet was covered with tires $\left(25 \mathrm{~kg} / \mathrm{m}^{2}\right)$, and the other half was covered with gravel $\left(200 \mathrm{~kg} / \mathrm{m}^{2}\right)$. The silo was opened during the summer and had a low feed-out rate $(12 \mathrm{~cm} / \mathrm{d})$. The results showed that the difference in sealing system affected the temperature in the peripheral areas of the corn silage. The silage covered with tires reached a maximum temperature of more than $40^{\circ} \mathrm{C}$, whereas temperatures never exceeded $30^{\circ} \mathrm{C}$ in silage covered with gravel.

The amount of soil placed on top of the plastic cover also has an effect on silage quality. Bernardes et al. (2009) studied the effectiveness of several sealing strategies on reducing losses in the top layer of tropical silages in Brazil. Covering with a black plastic sheet along with soil $\left(100 \mathrm{~kg} / \mathrm{m}^{2}\right)$ reduced losses and was associated with decreased $\mathrm{pH}$ and ash content and lower counts of yeasts. However, most farmers are very reluctant to cover horizontal silos with soil, particularly if the silo is large, as they do not believe that the labor and costs can be economically justified. Moreover, the soil used as a cover can contaminate the silage during unloading. Thus, alternative covering strategies to reduce aerobic deterioration of the top layer in bunkers filled with corn silage were investigated. Three treatments were evaluated: (1) black film (control), (2) black film plus sugarcane bagasse $\left(10 \mathrm{~kg} / \mathrm{m}^{2}\right)$ over the sheet, and (3) black film plus soil $\left(30 \mathrm{~kg} / \mathrm{m}^{2}\right)$ over the sheet (Amaral et al., 2010). Treatments did not affect the temperatures during the early part of the storage period, but after about $80 \mathrm{~d}$ of fermentation the temperature in the control silage was higher than that in other treatments. This can be attributed to increased permeation of oxygen through the film during prolonged storage, as permeation was reduced by the presence of soil or sugarcane bagasse over the sheet.

It is important to emphasize that keeping the plastic cover weighed down is critical during storage and feedout periods. Honig (1991) reported that during unloading, air can penetrate the peripheral areas of a silo by up to $1 \mathrm{~m}$ beyond the feed-out face, especially when the sealing cover is not weighted down or is weighted only with tires. This suggests that with this situation, daily removal rates should be higher than $30 \mathrm{~cm} / \mathrm{d}$ to avoid extended aerobic spoilage.

Feed-Out Rate. Losses during unloading depend on the density of the silage, the ambient temperature, the aerobic stability of the silage, and feed-out rate, which determines the duration that the silage is exposed to air (Muck et al., 2003). The prevailing temperature during unloading depends on the season and geographical location of the silo. In the Netherlands (latitude $53^{\circ}$ $\mathrm{N}$ ), silo face removal rates of 1 to $1.5 \mathrm{~m} /$ wk (winter and summer, respectively) were recommended by Vissers et al. (2007) to avoid extended aerobic spoilage. An average removal rate of 1.1 to $2.1 \mathrm{~m} /$ wk from the silo face is a common recommendation in Wisconsin (latitude $44^{\circ} \mathrm{N}$; Pitt and Muck, 1993). Under subtropical conditions, such as in Israel (latitude $31^{\circ} \mathrm{N}$ ), recommended bunker silo unloading rates are 1.4 to $2.1 \mathrm{~m} /$ wk (winter and summer, respectively). Unfortunately, there is no definitive answer for the correct feed-out rate in tropical regions. Borreani and Tabacco (2012) reported a high correlation $\left(\mathrm{R}^{2}=0.84\right)$ between feed-out rates and average seasonal temperatures from 6 countries. Based on their data, it can be inferred that under warm conditions, feed-out rates below $2.0 \mathrm{~m} / \mathrm{wk}$ do not prevent aerobic deterioration even if good silo management practices are used. As a general recommendation, to 
ensure a correct feed-out rate, the daily amount of silage consumed by the herd and the average temperature during the unloading period should be taken into account in advance of silo sizing and filling.

\section{Barriers Faced by Farmers in Hot Regions}

Generally, farming systems in tropical regions can be categorized as either low or high input. In high-input intensive systems, the aim is to produce high-quality silage to feed livestock of medium or high genetic merit (e.g., Holstein cattle). In low-input systems, farmers raise native livestock and have a goal of subsistence farming (Adesogan, 2009). Thus, low-input silage production systems are subject to specific restrictions as discussed below.

Economics. Because advanced machines for optimizing silage production are unaffordable in low-input systems, many farmers borrow equipment from neighbors, the municipal government, or cooperatives. This practice can lead to negative consequences because the crop is not always harvested, chopped, transported, and packed properly. Those producers who are able to purchase equipment select simpler, less expensive machines (e.g., harvesters pulled by a tractor). In Brazil, the use of pull-type forage harvesters is still very common (Bernardes and Rêgo, 2014), mainly due to the high cost of self-propelled harvesters. This scenario is different from that observed in other countries with a tradition of conserving forages as silage. According to Muck and Shinners (2001), worldwide sales of traditional machines decreased from 7,000 units in 1990 to 3,500 in 1995, whereas the sales of self-propelled harvesters increased from 1,800 to 2,500 units within the same period. Aside from the ensiling process, the lack of equipment is also reflected during the unloading phase, as many farmers remove silage manually using hand forks or shovels.

Ensiling Expertise. Producers in most tropical low-input systems lack information on the best agronomic and management practices for enhancing silage preservation. In 2013, 260 Brazilian dairy farmers answered a survey asking how often they sharpen the harvester knives (Bernardes and Rêgo, 2014). Only $54.6 \%$ of the respondents indicated that they sharpen the knives of the harvesters daily. Half of the farmers reported sharpening only at the beginning of the harvest $(26.9 \%)$, every $2 \mathrm{~d}(11.2 \%)$, or less frequently than every $2 \mathrm{~d}(7.3 \%)$.

Regarding the filling phase of the silo, a study involving 32 dairy farms in Brazil showed that farmers tend to overfill bunker silos (T. F. Bernardes, I. L. De Oliveira, and L. M. Lima, Department of Animal Sci- ence, Federal University of Lavras, Brazil; unpublished data). In this study, overfilled silos had poorer fermentation and higher yeast counts in the upper layers of the mass compared with farms where corn silages were maintained below the sidewalls of the bunker.

With respect to silage sealing, several producers still use black plastic for covering silos (Bernardes and Rêgo, 2014), which is considered to be a poor practice. Snell et al. (2003) reported the effects of color on the temperature of the film surfaces. They determined that during the morning hours, temperature peaks were up to $16^{\circ} \mathrm{C}$ higher for black film compared with white film. In these systems, several producers also ignored the effects of spoiled silage on feed intake and on the nutritive value of the diet; they did not discard silage with a deteriorated appearance but rather fed it directly to cattle (Bernardes and Rêgo, 2014).

\section{SILAGE MAKING IN COLD REGIONS}

Growing forages under cold climatic conditions offers challenges that can vary with high humidity, drought, or short growing seasons. Forage production in cold regions is mostly conducted under short growing seasons and low temperatures, with an annual pattern dominated by a long dormancy period corresponding to the winter months. In some of the less-favored cold regions of North America and Northern Europe, production of forage and associated livestock, including dairy cattle, beef cattle, sheep, goats, and horses, is often the only agricultural activity possible. Short and cool growing seasons along with harsh winter conditions limit the choice of perennial grasses and legumes, which might result in lower nutritive value than in areas with more favorable growing conditions. For instance, the most widely used perennial forage species in eastern Canada and the Nordic countries include timothy (Phleum pratense L.), perennial ryegrass (Lolium perenne L.), and tall fescue [Schedonorus arundinaceus (Schreb.) Dumort]. The latter 2 forage species are known for their greater nutritive value and sugar concentration than timothy and are widely grown in the United Kingdom, continental Europe, and the northern United States. However, they have limited acreage in more northern areas of Canada and the Nordic countries because of their lack of winter hardiness. Red clover (Trifolium pratense L.), a forage legume species, is widely used in the northern areas of North America and Nordic countries and tends to have a lower NDF concentration and greater DM and NDF digestibilities than alfalfa (Medicago sativa L.; Pelletier et al., 2010).

Cold-season grasses and legumes are typically harvested in a bimodal manner that is dictated by season 
(Balasko and Nelson, 2003), with high levels of DM production in the spring followed by a second DM production period in late summer to early fall. Most forage species cultivated in cold climates are perennials that have root systems that are able to store energy to enable plant survival over the winter. Winter cereals are also used to improve field management and are sown in the autumn to either germinate after a summer crop or harvest the following spring, before planting of the next seasonal crop.

Winter hardiness could be defined as the capacity of a plant to tolerate freezing and subsequent injury to aboveground tissues and root systems from low temperature and ice. Annual losses in the field due to winterkill of alfalfa can be as high as $78 \%$ (Ouellet, 1976). Acclimation to lower temperature is a progressive mechanism that allows plants to survive the winter. One adaptation for survival at low temperatures is that freezing of plant tissues is limited to extracellular spaces. Accumulation of different solutes, such as glycine (Ferullo et al., 1997), protects the cell from desiccation induced by changes in vapor pressure between intra- and extracellular compartments (Belanger et al., 2002).

A longer photosynthesis period due to the Earth's orbital inclination in early summer contributes to the high DM production during this season in colder regions. Most of the sugars produced are used to build structural carbohydrates that increase yield, but some sugars are transported to the roots, where they accumulate in storage structures. For example, timothy accumulates $\beta(2,6)$-linked fructans of high degrees of polymerization in its roots (Cairns et al., 1999). Fructans are easily translocated to different organs and can act as defensive molecules that serve as membrane protectors that increase the tolerance of plants to low temperatures (Thorsteinsson et al., 2002; Van den Ende et al., 2004).

The nutritive value of cool-season forage grasses is known to be affected by air temperature, and higher nutritive value is expected when forage crops are grown under the cool conditions (Buxton and Fales, 1994) encountered at higher latitudes. For instance, cool-season grasses generally have a higher concentration of NFC when grown at cool temperatures $\left(5-10^{\circ} \mathrm{C}\right)$ than when grown at warm temperatures $\left(15-25^{\circ} \mathrm{C}\right.$; Deinum et al., 1968; Chatterton et al., 1989). Low temperatures are also known to improve forage digestibility through a reduction in lignification (Deinum et al., 1981; Thorvaldsson et al., 2007; Bertrand et al., 2008) and a corresponding improvement in digestibility (Thorvaldsson et al., 2007).

The possibility of growing higher yielding annual crops such as corn silage is limited by the short and cool growing seasons in northern areas. Short growing seasons and long, cold winters also limit the grazing season to less than 6 mo in many areas and therefore increase the dependence on conserved forage with a corresponding requirement for harvesting equipment, storage structures, and optimal forage conservation. In most cold and humid regions forages are conserved as silages, and their quality is critical for the feeding of high-quality forages to dairy and beef cattle.

\section{Increasing Sugar Concentration of Perennial Forage Species in Cold Regions}

Forage yield, digestibility, CP concentration, mineral composition, and functional compounds are all important attributes that are affected directly or indirectly by climate. This section focuses mainly on nonstructural carbohydrates because along with affecting the feed value, they also affect ensiling potential. Nonstructural carbohydrates are the main source of fermentable substrates during ensiling, and they are an important source of readily fermentable energy for rumen microbes. They include WSC (i.e., glucose, fructose, sucrose, and fructans) and starch. Factors that affect plant growth and metabolism, such as climate, harvest management, and fertilization, are also likely to affect forage NFC concentration. Several strategies exist to increase the concentration of NFC in forages grown in cold areas.

Morning Versus Afternoon Cutting and Swath Management. Plant carbohydrate concentration increases during the day, when photosynthetic carbohydrate synthesis exceeds utilization. This opens the possibility of cutting at a time during the day when NFC concentrations are the highest. Studies conducted with different forage species in North America, including the more northern areas, have shown that cutting later in the day results in forages with greater NFC concentrations, particularly on sunny days (Fisher et al., 1999, 2002; Burns et al., 2005, 2007). The highest NFC concentrations usually occur between 11 and $13 \mathrm{~h}$ after sunrise in both alfalfa (Morin et al., 2011) and timothy (Morin et al., 2012a); this optimal time period is the same in spring, summer, and autumn for alfalfa (Morin et al., 2012b).

Plant cells remain viable after cutting and continue to use NFC for respiration until they die. In the northern agricultural area of eastern Canada, alfalfa NFC concentration progressively decreased at a rate ranging from 0.2 to $3.5 \mathrm{~g} / \mathrm{kg}$ of DM per hour during the first day of wilting (Morin et al., 2012b). This rate of decrease in NFC concentration was not affected by the time of cutting (a.m. vs. p.m.). Consequently, p.m.cut alfalfa still has greater NFC concentrations than 
a.m.-cut alfalfa at the end of the wilting period under optimal drying conditions. It is often thought that PMcut alfalfa will lose a significant proportion of its NFC during the night, hence losing its advantage over a.m.cut alfalfa. However, recent research has shown that nighttime NFC losses in late p.m.-cut alfalfa, although variable, are low and that these losses are more than compensated by early morning photosynthesis of cut and unwilted alfalfa. Photosynthesis of late p.m.-cut alfalfa continues for up to $3 \mathrm{~h}$ after the morning cutting until DM concentrations reach approximately $350 \mathrm{~g}$ of $\mathrm{DM} / \mathrm{kg}$ (Morin et al., 2012b). The late p.m.-cut alfalfa laid directly on the ground without swathing, having not wilted during the night, can resume photosynthesis the following morning ( 1 of wilting) at the same rate as a.m.-cut alfalfa and standing alfalfa.

Wilting conditions affect forage NFC concentrations. Fast drying reduces respiration time and, consequently, the oxidation of NFC. Alfalfa cut and laid directly on the ground reduces wilting time by up to $9 \mathrm{~h}$ under poor drying conditions and exhibits increased NFC concentrations compared with alfalfa that is swathed and dried in windrows. Therefore, late p.m. cutting and wilting of alfalfa in wide swaths are agronomic practices that can be used to increase NFC concentrations (Morin et al., 2012b). When wilting conditions are conducive for rapid drying and with 2 consecutive sunny days, producers using this practice can produce wilted alfalfa forage with greater NFC concentrations in less than $24 \mathrm{~h}$. Some NFC, such as fructans in timothy, are prone to degradation during the wilting period, partly due to higher activities of specific hydrolase enzymes (Ould-Ahmed et al., 2015). Increasing fructose concentration through a reduction in fructan degradation during wilting could improve the ensiling potential of timothy. The metabolic regulation of reserve carbohydrates in forages, such as starch or fructans, is complex and involves multiple genes and biochemical pathways (Ould-Ahmed et al., 2014). Fructans are easily degraded during ensiling (Merry et al., 1995), but the rate of degradation is uncertain because it is not known to what extent fructan exohydrolases remain active during wilting (Ould-Ahmed et al., 2015). The fate of these carbohydrates during ensiling is also unclear; in one study, only $2 \%$ of LAB possessed the ability to degrade this polysaccharide (Winters et al., 1998).

Soluble carbohydrates such as glucose, fructose, and sucrose are quantitatively the most important substrates for silage fermentation. Consequently, concentrations of NFC decrease during fermentation, and the extent of this decrease in NFC concentration varies with silage DM concentration. The resulting decrease in NFC concentration during fermentation may offset the gains in nutritive value achieved by harvesting the forage at high NFC concentration. As outlined above, concentration of NFC in alfalfa increases if the alfalfa is cut in the afternoon and wilted in wide swaths. Tremblay et al. (2014) investigated the implication of this practice for silage fermentation. Differences in alfalfa NFC concentration at ensiling (10 to $36 \mathrm{~g} / \mathrm{kg}$ of DM) due to p.m. cutting, with or without wide swaths, were reduced during ensiling to between 0 and $15 \mathrm{~g} / \mathrm{kg}$ of DM, mostly as a result of the utilization of NFC. When NFC concentration differences at ensiling due to p.m. cutting were greater than $10 \mathrm{~g} / \mathrm{kg}$ of DM, silage conservation attributes were improved with lower $\mathrm{pH}(-0.2$ to -0.4$)$, greater concentrations of lactate $(+8$ to +20 $\mathrm{g} / \mathrm{kg}$ of DM), and lower concentrations of VFA ( -8 to $-11 \mathrm{~g} / \mathrm{kg}$ of DM) and ammonia nitrogen ( -6 to $-11 \mathrm{~g} /$ $\mathrm{kg}$ of total N). Improved silage conservation attributes, along with a greater residual starch concentration from NFC-enriched alfalfa, have the potential to increase the nutritive value of silage and improve milk production.

Species, Stages of Development, and Season. Producers in temperate and cold areas have access to several forage species and mixtures, but there is little information on which species and mixtures result in the highest NFC concentrations. Legumes are often thought of as having lower NFC concentrations than grasses. However, in a study conducted in eastern Canada, alfalfa had similar NFC concentration to timothy (Pelletier et al., 2010). Few studies have compared the NFC concentration among cool-season forage species. The limited available information indicates that red clover has a greater NFC concentration than alfalfa and that tall fescue has the highest NFC concentration among several cool-season grasses (Pelletier et al., 2010).

The NFC concentration may vary with stage of development at harvest, but results are inconsistent, partly because of the confounding effect of the climatic conditions on or near the time of harvest (Wilman, 2004). In a study conducted in the most northern agricultural area of eastern Canada ( 1,400 growing degree days), there were no consistent differences in forage NFC concentrations in tall fescue cut 2, 3, or 5 times per year (Drapeau et al., 2005). Shorter intervals between harvests did not influence NFC concentrations. However, in the fall, delaying harvest can result in significant increases in NFC as ambient air temperatures decrease. In the most northern agricultural area of eastern Canada, the NFC concentration of tall fescue increased from $60 \mathrm{~g} / \mathrm{kg}$ of DM in early September to $150 \mathrm{~g} / \mathrm{kg}$ of DM in late October (Drapeau et al., 2007). At less than optimal temperatures for growth, carbohydrates accumulate as photosynthesis generates NFC that are not immediately incorporated into plant tissues due to 
declining growth rates (i.e., photosynthesis continues at the same rate while growth slows).

Differences in NFC concentrations between spring and summer varied with the forage species in a study conducted in eastern Canada, and no general conclusions could be drawn (Pelletier et al., 2010). However, alfalfa harvested in early October had a greater NFC concentration than that harvested in June or August (128 vs. 91 and $102 \mathrm{~g} / \mathrm{kg}$ of DM, respectively) in an eastern Canadian study in a region with 1,700 growing degree days (Morin et al., 2012b). Perennial forage crops harvested in late fall (e.g., October in eastern Canada) are likely to have much greater NFC concentrations than those harvested in summer or early fall.

Nitrogen Fertilization. Lowering N fertilization has been shown to increase NFC and reduce CP concentrations of several cool-season grass species-for example, timothy, orchardgrass (Dactylis glomerata L.), and tall fescue (Pelletier et al., 2009) - but it may also reduce total yield. Timothy silage quality is reduced by increased application of $\mathrm{N}$ fertilizer, primarily at early developmental stages, and this can be attributed to a reduction in WSC concentration and an increase in the buffering capacity of the forage. Therefore, the ensiling properties of timothy are less favorable when high rates of $\mathrm{N}$ fertilizer are applied (Tremblay et al., 2005).

\section{Producing Corn Silage and Other Silage Crops in Cold Areas}

Corn growth and development are very sensitive to temperature. Corn is also sensitive to late spring frosts and early fall frosts. A short growing season and cool temperatures often limit the use of corn silage in cold areas. The successful introduction of short-season corn hybrids along with the current and projected warming of the climate has raised the interest in growing corn for silage in cold areas and could potentially open up large northern areas for corn silage production.

When grown in cool climates, short-season hybrids often fail to reach the recommended $340 \mathrm{~g} / \mathrm{kg}$ of wholeplant DM concentration before fall harvest (Ma et al., 2006). Ensiling immature corn forage in tower silos can result in excessive seepage losses and even freezing, and feeding immature corn silage can have negative effects on voluntary intake.

Harvest of corn silage is often delayed to obtain an adequate DM concentration. Producers in cold areas often use frost as a means of increasing DM concentration so that corn can be ensiled. These practices can affect feeding values of the forage. Calder et al. (1977) reported an $8 \%$ decrease in the DM digestibility of corn harvested after the first frost. Decreases in nitrogen, phosphorus, and potassium have also been observed after the first frost (White et al. 1976). Although these authors did not mention the severity of the frost events, St Pierre et al. (1987) observed that exposing corn to up to 2 frosts resulted in higher silage intake and $4 \% \mathrm{FCM}$ production. In a study conducted in a region with fewer than 2,300 corn heat units in Québec, Canada, delaying the harvest by $31 \mathrm{~d}$ after the first frost increased the DM concentration from 306 to 461 $\mathrm{g} / \mathrm{kg}$ of fresh matter (Drapeau et al., 2002). However, delaying the corn harvest until after the first frost was shown to decrease yield by $38 \mathrm{~kg}$ of $\mathrm{DM} /$ ha per day and to increase the NDF concentration by $0.68 \mathrm{~g} / \mathrm{kg}$ of DM per day. These changes in yield and nutritive value translate into a reduction in estimated milk production of $68 \mathrm{~kg} / \mathrm{ha}$ for each day of delayed harvest (Drapeau et al., 2002). Early fall frosts of corn may also reduce the level of beneficial silage bacteria (primarily LAB) on the standing plant and elevate numbers of spoilage organisms such as yeasts and molds. However, frostdamaged corn can still be ensiled even without the use of inoculants (Mohammadzadeh et al., 2012, 2014).

Reed canary grass (Phalaris arundinacea L.), a highyielding cool-season grass species recommended for forage production in the northern areas of North America, and switchgrass (Panicum virgatum L.), a perennial warm-season grass species native to the North American prairies, are also potential perennial herbaceous biomass crops for energy production. These grass species are likely to be conserved as silage before their use in anaerobic digesters for methane production and even for cellulosic ethanol production. Although their ensiling potential as forage crops is relatively well known, very few studies have looked at their ensiling potential when harvested once a year late in the season. Results from studies conducted in eastern Canada confirm the high yield and ensiling potential of both species as an energy crop in northern latitudes. Silage attributes $(\mathrm{pH}$ and concentrations of lactate and ammonia nitrogen) also reflected adequate fermentation during ensiling (Belanger et al., 2012, 2016).

The growth potential of sweet pearl millet $[\mathrm{Pen}$ nisetum glaucum (L.) R.Br] and sweet sorghum [Sorghum bicolor (L.) Moench] under the cool and humid conditions of eastern Canada was also demonstrated in recent years. Both forages were deemed to have potential as sources of biomass for biofuel production due to their high sugar yields. The bagasse produced as a result of the extraction of the NFC from these forages for ethanol production could also be preserved as silage and used as an animal feed. Presently, the nutritive and conservation attributes of bagasse silage from sweet sorghum and sweet pearl millet grown in the northern 
areas are not well known. A recent study showed that extraction of the NFC from the biomass of sweet pearl millet and sweet sorghum reduced the nutritive value of the residue but did not impair its ability to be ensiled (Dos Passos Bernardes et al., 2016).

\section{Effects of Cold Conditions on Silage Conservation}

For most of the growing season, ensiling conditions at northern latitudes are conducive to the production of silage. Ambient temperatures are usually above $15^{\circ} \mathrm{C}$ during the day but still can decrease significantly during the night. These fluctuations in temperature can cause the formation of dew, which increases surface moisture on the wilted forage. Although there are no published results on the effect of dew on the microbial community, prolonging wilting will have a negative effect on the residual carbohydrates, lipids, and protein content of the forage (Papadopoulos and McKersie, 1983; Liu et al., 2011; Edmunds et al., 2012; Van Ranst et al., 2013).

Harvesting forages at the northern limits of their cultivation (e.g., corn) can also make these forages more difficult to ensile. As the temperatures decline in the fall, the cool nights and often frequent frosts result in a decline in the metabolic activity of the forage as the plant enters senescence. This influences the epiphytic bacterial population, as freezing can lyse plant cells and release soluble carbohydrates (Melick and Seppelt, 1992) that are metabolized by the plant microbiome (Sanaullah et al., 2010). The lower mean daily temperature can also negatively affect the fermentation process (Ali et al., 2015). Some silage additives can be functionally impaired at lower temperature because strains within silage inoculants are often selected at temperatures associated with warmer climates (Weinberg and Muck, 1996).

A study performed on corn incubated at different temperatures, from $25^{\circ} \mathrm{C}$ down to $5^{\circ} \mathrm{C}$ (Zhou et al., 2016), observed significant delays in the $\mathrm{pH}$ decline with decreasing temperatures during ensiling, although the terminal silage $\mathrm{pH}$ after $60 \mathrm{~d}$ was unaffected by temperature. Mini silos incubated at $5^{\circ} \mathrm{C}$ had a mean $\mathrm{pH}$ level of 5.0 after $30 \mathrm{~d}$ of fermentation. The diversity of the LAB population as determined by PCR-denaturing gradient gel electrophoresis, suggested that $15^{\circ} \mathrm{C}$ might be the lower limit for growth of L. buchneri. Still, other heterolactic species dominated the LAB population after $60 \mathrm{~d}$ of fermentation at temperatures below $15^{\circ} \mathrm{C}$ (Zhou et al., 2016). In this study the silage was not inoculated, so these observations were related to the epiphytic LAB population originally associated with the corn forage.

Studying the effect of low temperatures on the fermentation potential of TMR silages ensiled during spring, summer, fall, or winter, Cao et al. (2011) observed that LAB counts and corresponding activities were lower for silages prepared in winter. As silages were stored outdoors, ambient temperature changed daily, reaching a minimum of $-2^{\circ} \mathrm{C}$. For most conditions, the initial $\mathrm{pH}$ of the TMR silages was between 5.22 and 5.44 and decreased by $1 \log$ under moist conditions after $60 \mathrm{~d}$ of fermentation. The degree of decline in $\mathrm{pH}$ was even lower under colder conditions.

Ensiling wheat straw $(32 \% \mathrm{DM})$ at $5^{\circ} \mathrm{C}$ for 30 or 60 $\mathrm{d}$ and inoculating it with $L$. plantarum strains selected for growth at low temperatures improved silage fermentation compared with a control strain (Zhang et al., 2017). Another study of ensiling at low temperature was undertaken by Wang et al. (2011), who investigated the effects of LAB inoculants on the fermentation quality of reed grass (Phragmites australis Cav. Trin. ex Sterd.). Two fermentation conditions were tested: 0 and $4^{\circ} \mathrm{C}$. As expected, lower temperatures slowed the rate and extent of fermentation. However, some of these negative outcomes were reversed after 6 wk of ensiling if the silage was inoculated with the LAB inoculant at $6.63 \mathrm{log} \mathrm{cfu} / \mathrm{g}$ of forage (Wang et al., 2011).

\section{Constraints and Potentialities of Round Bale Silage in Cold Regions}

Round bale silage has become a common method of forage preservation in northern climates, particularly in Northern Europe. For example, in Finland approximately one third of grass silage is conserved as round bales (J. Nousiainen, Valio Ltd. Farm Services, Valio, Finland; personal communication), and in Sweden this method accounts for as much as 50\% (R. Spördly, Swedish University of Agricultural Sciences, Uppsala, Sweden; personal communication) of the conserved forage. Round bale systems have advantages over chopped silage systems, such as a lower capital investment and flexibility in feeding (Muck and Shinners, 2001). The system is also more flexible when the distance from the field to the point of feeding is longer. In field trials, preservation as round bale silage reduced DM losses and improved nutritive value compared with hay (Han et al., 2004). Wilting, treatment with additives, chopping, and increased bale density (Jonsson et al., 1990; Han et al., 2004; Slottner and Bertilsson, 2006) can also result in improved silage quality.

The results of analysis of on-farm silage samples in Finland indicated that the fermentation quality and nutritive value of round bale silages are comparable to that of silages preserved in bunker silos (Table 1). The concentration of DM was greater in round bale silages than in bunker silo silages, which explains the higher $\mathrm{pH}$ and less extensive fermentation. Both silages 
were of high quality as reflected by low concentrations of ammonia nitrogen. The variables of nutritive value were similar between the 2 ensiling methods, indicating that on average the silages were harvested at the same stage of maturity (Table 1).

Although new equipment can improve fermentation efficiency by generating bales with a higher density and enabling the chopping of the forage, bales still usually have a lower density than forage packed in bunker or pile silos. The higher oxygen concentration inside bales can delay the fermentation, enabling more sugars to be metabolized by plant cells.

Good-quality baling should be performed at a higher DM level to improve long-term storage. The ideal DM range should be between 400 and $450 \mathrm{~g} / \mathrm{kg}$ of forage. This range is ideal for LAB and will limit the growth of several undesirable microorganisms (McEniry et al., 2008). Frequently, bales of higher DM level are generated on farms. As a result the elevated osmotic pressure negatively affects the activity of LAB, generating a higher $\mathrm{pH}$ that allows the growth of yeasts and molds.

Daily changes in ambient temperature can also promote condensation on the inner layer of plastic, creating conditions that are favorable for the growth of yeast, molds, or other spoilage microorganisms (McEniry et al., 2008). Bales have a higher surface:volume ratio than bunker silos and, as a result, core temperatures in bales decline more rapidly than in bunker silos. This lower internal temperature can affect the microbial succession and metabolism of microorganisms during ensiling (Forristal and O'Kiely, 2005).

Stretch film plastic used to wrap bales is sensitive to physical damage, either from handling or from animals. Generally, silage bales wrapped with 6 layers of stretch film were more secure against physical damage during bale handling than bales with fewer layers (O'Brien et al., 2007). Oxygen ingress will promote deterioration of the silage, promoting the growth of aerobic spoilage microorganisms in localized regions. Clostridia can also become established if regions within the bale exhibit the elevated $\mathrm{pH}$ that allows their growth (Jonsson et al., 1990).

\section{Improving Silage Fermentation Through Acid-Based Additives in Cold Regions}

Using acid-based additives to control silage fermentation originates from the classical work by Virtanen (1933). His method was based on reducing herbage $\mathrm{pH}$ below 4 by direct applications of mixtures of sulphuric and hydrochloric acids. The idea was that direct acidification prevented clostridial fermentation and reduced proteolysis. The corrosive nature of inorganic
Table 1. Composition and fermentation quality of on-farm silage samples in Finland from 2014 to 2016

\begin{tabular}{lcc}
\hline Item, g/kg of DM unless stated & Round bale & Bunker silo \\
\hline No. of samples & 35,593 & 21,505 \\
DM, g/kg as fed & 369 & 301 \\
pH & 4.33 & 4.00 \\
CP & 137 & 142 \\
NDF & 533 & 531 \\
Indigestible NDF & 75 & 73 \\
Lactic acid & 41 & 56 \\
VFA & 11 & 16 \\
Ammonia N, g/kg of N & 44 & 42 \\
OM digestibility, g/kg & 722 & 725 \\
\hline
\end{tabular}

acids eventually led to the abandonment of inorganic acids as silage preservatives. Research in Norway (Saue and Breirem, 1969) demonstrated the effectiveness of formic acid, which rapidly became the most commonly used acid-based silage additive. Low $(2-2.5 \mathrm{~L} / \mathrm{t})$ levels of formic acid favor the growth of epiphytic LAB and facilitate the rapid decline in $\mathrm{pH}$, reducing proteolysis. At high (4-5 L/t) rates of application, direct acidification restricts fermentation, thereby increasing the concentration of residual WSC. The study by Jaakkola et al. (2006) clearly demonstrated the effects of increased application rates on silage fermentation quality. The lowest level $(2 \mathrm{~L} / \mathrm{t})$ slightly decreased the extent of fermentation and considerably reduced acetic acid production and proteolysis. Higher levels $(4-6 \mathrm{~L} / \mathrm{t})$ of formic acid further restricted the extent of fermentation and proteolysis and resulted in the highest concentration of residual WSC.

Formic acid has a selective bactericidal effect, but it is not particularly effective against yeasts (McDonald et al., 1991). Even a small amount of oxygen may initiate the growth of the yeasts and molds that are responsible for aerobic deterioration. The use of combinations of hexamethylene tetraamine, sodium nitrite, sodium benzoate, and sodium propionate has improved the quality and storage stability of silage made from wilted grass (Lingvall and Lättemäe, 1999; Knicky and Spörndly, 2009). Currently, when wilting is a common practice, most commercial acid-based silage additives contain propionic acid, benzoic acid, or other organic acids that are more effective against yeasts and molds.

In addition to ensuring good fermentation quality and smaller ensiling losses, acid-treated silages affect both total nutrient intake and the profile of absorbed nutrients. According to a meta-analysis by Huhtanen et al. (2007), silage DMI is negatively influenced by the total acid concentration in silage. In this analysis, the effect on DMI did not differ between homolactic and heterolactic silage fermentations. However, according to Eisner et al. (2006), the predicted intake 
Table 2. Effects of total acid concentration in silage $(\mathrm{g} / \mathrm{kg}$ of $\mathrm{DM})$ when analyzed with univariate or bivariate analysis $^{1}$

\begin{tabular}{|c|c|c|c|c|c|c|}
\hline \multirow[b]{2}{*}{ Item } & \multicolumn{3}{|c|}{ Univariate model } & \multicolumn{3}{|c|}{ Bivariate model } \\
\hline & Estimate & $\mathrm{SE}$ & $P$-value & Estimate & $\mathrm{SE}$ & $P$-value \\
\hline Milk, kg/d & -7.3 & 2.4 & 0.003 & 0.8 & 0.98 & 0.78 \\
\hline $\mathrm{ECM}, \mathrm{kg} / \mathrm{d}$ & -18.6 & 2.6 & $<0.001$ & -5.8 & 3.0 & 0.05 \\
\hline \multicolumn{7}{|l|}{ Milk composition, $\mathrm{g} / \mathrm{kg}$} \\
\hline Fat & -0.030 & 0.003 & $<0.001$ & -0.029 & 0.004 & $<0.001$ \\
\hline Protein & -0.015 & 0.0019 & $<0.001$ & -0.032 & 0.005 & $<0.001$ \\
\hline \multicolumn{7}{|l|}{ Yield, g/d } \\
\hline Fat & -1.06 & 0.12 & $<0.001$ & -0.47 & 0.13 & 0.003 \\
\hline Protein & -0.50 & 0.08 & $<0.001$ & -0.19 & 0.1 & 0.07 \\
\hline
\end{tabular}

${ }^{1}$ In bivariate analysis, silage DMI was used as a covariate. Data from Huhtanen et al. (2003).

of silages undergoing a secondary fermentation can be improved by including acetic acid or VFA in the model (Eisner et al., 2006). The mechanisms of increased DMI of acid-treated silages with restricted fermentation are not entirely known. Reduced DMI of extensively fermented silages can be related partly to palatability attributes and partly to the changes in the profile of absorbed nutrients. The efficiency of microbial protein synthesis is lower in animals fed extensively fermented silages (Harrison et al., 2003; Jaakkola et al., 2006), resulting in a lower AA:ME ratio in absorbed nutrients. Similarly, high-quality protein supplements result in increased silage DMI (e.g., Oldham, 1984). Another possible mechanism suggested by Allen et al. (2009) is the hepatic oxidation theory. Of the fuels metabolized in the liver of ruminants, propionate produced from silage lactate is likely a primary satiety signal because its flux to the liver increases with each meal. Propionate is utilized for gluconeogenesis or oxidized in the liver and stimulates the oxidation of acetyl CoA.

The extent of in-silo fermentation of WSC has a strong influence on ruminal fermentation patterns. Increased concentration of silage lactic acid increases propionate concentrations in the rumen. Intraruminal infusions of lactic acid demonstrated that propionate is the main end product of lactate fermentation (Jaakkola and Huhtanen, 1992; Choung and Chamberlain, 1993). Increased lactic acid concentration in silage consistently results in increased propionate concentrations in the rumen (Harrison et al., 2003), whereas higher WSC concentrations in silages treated with formic acid tend to increase either ruminal acetate or butyrate.

The end products of silage fermentation (lactic acid, VFA) provide little or no ATP for rumen microbes (Chamberlain, 1987). As a result of a higher concentration of WSC in silages treated with formic acid, ruminal microbial protein synthesis is increased compared with more extensively fermented silages (Harrison et al., 2003; Jaakkola et al., 2006). In addition to greater ATP supply from restrictively fermented versus extensively fermented silages, microbial growth can be stimulated by a more optimal $\mathrm{N}$ profile in the silage, especially by higher concentrations of peptide $\mathrm{N}$ (Nsereko and Rooke, 2000).

A meta-analysis of data from studies investigating the effects of the extent of in-silo fermentation manipulated by different additives (Table 2; Huhtanen et al., 2003) indicated that an increased concentration of total acids in silage was associated with reduced yield of ECM, milk fat, and protein, but yield was unaffected. Milk concentrations of fat and protein decreased with increasing total acid concentration in silage. These changes can be attributed to the total energy supply and changes in the profile of absorbed nutrients. Higher milk fat concentration with restrictively fermented silages is related to increased proportion of lipogenic VFA in rumen fluid, and the higher milk protein concentration is linked to an increase in DMI and improved efficiency of microbial protein synthesis. However, when DMI was used as a covariate in the model, only the effect on milk fat concentration and yield of ECM remained statistically significant, suggesting that DMI was the main driver of production responses in cows fed different silages.

In conclusion, although the use of bacterial inoculants as silage additives has increased in Northern Europe, acid-based additives are still a good option, especially in difficult weather conditions, to ensure good fermentation quality and high intake potential and nutritive value of silages.

\section{FINAL REMARKS}

Climatic conditions affect all stages of silage production and utilization, from the field to the feed bunk. All abiotic components can influence silage quality; however, among them, temperature (high or low) seems to be the most limiting factor. Although the availability of 
financial resources is not directly affected by climate, in hot regions there are more low-input farming systems, which can also impair silage quality.

\section{REFERENCES}

Adesogan, A. T. 2009. Challenges of tropical silage production. Pages 139-154 in Proc. 15th Intl. Silage Conf., Madison, WI. University of Wisconsin, Madison.

Adesogan, A. T. 2010. Corn silage quality in tropical climates. Pages 311-327 in Proc. 5th Symp. Strategic Management of Pasture, Viçosa, Brazil. University of Viçosa, Viçosa, Brazil.

Ali, M., J. W. Cone, N. A. Khan, W. H. Hendriks, and P. C. Struik. 2015. Effect of temperature and duration of ensiling on in vitro degradation of maize silages in rumen fluid. J. Anim. Physiol. Anim. Nutr. (Berl.) 99:251-257.

Allen, M. S., B. J. Bradford, and M. Oba. 2009. Board-invited review: The hepatic oxidation theory of the control of feed intake and its application to ruminants. J. Anim. Sci. 87:3317-3334.

Amaral, R. C., B. C. Queiroz, E. H. C. Garcia, A. Sá Neto, T. F. Bernardes, and L. G. Nussio. 2010. Aerobic deterioration in maize silages under different covering methods of the plastic film. Pages 83-84 in Proc. 23rd General Meeting of the European Grassland Federation, Kiel, Germany. University of Göttingen, Göttingen, Germany.

Ashbell, G., Z. G. Weinberg, Y. Hen, and I. Filya. 2002. The effects of temperature on the aerobic stability of wheat and corn silages. J. Ind. Microbiol. Biotechnol. 28:261-263.

Ávila, C. L. S., C. E. C. Bravo Martins, and R. F. Schwan. 2010. Identification and characterization of yeasts in sugarcane silages. J. Appl. Microbiol. 109:1677-1686.

Balasko, J. A., and C. J. Nelson. 2003. Grasses for northern areas. Pages 125-148 in Forages. Vol. 1. R. F. Barnes, C. J. Nelson, M. Collins, and K. J. Moore, ed. Iowa State University Press, Ames.

Bassu, S., N. Brisson, J. L. Durand, K. Boote, J. Lizaso, J. W. Jones, C. Rosenzweig, A. C. Ruane, M. Adam, C. Baron, B. Basso, C. Biernath, H. Boogaard, S. Conijn, M. Corbeels, D. Deryng, G. De Sanctis, S. Gayler, P. Grassini, J. Hatfield, S. Hoek, C. Izaurralde, R. Jongschaap, A. R. Kemanian, K. C. Kersebaum, S.-H. Kim, N. S. Kumar, D. Makowski, C. Muller, C. Nendel, E. Priesack, M. V. Pravia, F. Sau, I. Shcherbak, F. Tao, E. Teixeira, D. Timlin, and K. Waha. 2014. How do various maize crop models vary in their responses to climate change factors? Glob. Change Biol. 20:2301-2320.

Belanger, G., P. Rochette, Y. Castonguay, A. Bootsma, D. Mongrain, and D. A. J. Ryan. 2002. Climate change and winter survival of perennial forage crops in Eastern Canada. Agron. J. 94:1120-1130.

Belanger, G., P. Savoie, G. Parent, A. Claessens, A. Bertrand, G. F. Tremblay, D. Masse, Y. Gilbert, and D. Babineau. 2012. Switchgrass silage for methane production as affected by date of harvest. Can. J. Plant Sci. 92:1187-1197.

Belanger, G., G. F. Tremblay, A. Bertrand, D. Mongrain, G. Parent, P. Savoie, D. Masse, Y. Gilbert, and D. Babineau. 2016. Reed canarygrass crop biomass and silage as affected by harvest date and nitrogen fertilization. Can. J. Plant Sci. 96:413-422.

Benton, J. R., T. Klopfenstein, and G. E. Erickson. 2005. Effects of corn moisture and length of ensiling on dry matter digestibility and rumen degradable protein. Pages 31-33 in Nebraska Beef Cattle Reports. University of Nebraska, Lincoln.

Bernardes, T. F. 2016. Advances in silage sealing. Pages 53-62 in Advances in Silage Production and Utilization. Vol. 1. T. Da Silva and E. M. Santos, ed. InTech, Rijeka, Croatia.

Bernardes, T. F., I. L. De Oliveira, M. A. S. Lara, D. R. Casagrande, C. L. S. Ávila, and O. G. Pereira. 2015. Effects of potassium sorbate and sodium benzoate at two application rates on fermentation and aerobic stability of maize silage. Grass Forage Sci. 70:491-498.

Bernardes, T. F., L. G. Nussio, R. C. Amaral, and A. L. B. Schogor. 2009. Sealing strategies to control the top losses of corn silage. Pages 213-214 in Proc. 15th Int. Silage Conf., Madison, WI. University of Wisconsin, Madison.
Bernardes, T. F., and A. C. Rêgo. 2014. Study on the practices of silage production and utilization on Brazilian dairy farms. J. Dairy Sci. 97:1852-1861.

Bernardes, T. F., R. A. Reis, and A. L. Moreira. 2005. Fermentative and microbiological profile of marandu-grass ensiled with citrus pulp pellets. Sci. Agric. 62:214-220.

Bertrand, A., G. F. Tremblay, S. Pelletier, Y. Castonguay, and G. Bélanger. 2008. Yield and nutritive value of timothy as affected by temperature, photoperiod and time of harvest. Grass Forage Sci. 63:421-432.

Bonner, R. D., and C. L. Fergus. 1960. The influence of temperature and relative humidity on growth and survival of silage fungi. Mycopathologia 52:642-647.

Borreani, G., T. F. Bernardes, and E. Tabacco. 2008. Aerobic deterioration influences fermentative, microbiological and nutritional quality of maize and sorghum silages on farm in high quality milk and cheese production chains. Rev. Bras. Zootec. 37:68-77.

Borreani, G., and E. Tabacco. 2007. Il silomais: Guida pratica [Corn silage: A practical guidance]. Quaderni della Regione PiemonteAgricoltura, Torino, Italy.

Borreani, G., and E. Tabacco. 2012. Effect of silo management factors on aerobic stability and extent of spoilage in farm maize silages. Pages 71-72 in Proc. 16th Int. Silage Conf., Helsinki, Finland. University of Helsinki, Helsinki, Finland.

Borreani, G., and E. Tabacco. 2014. Improving corn silage quality in the top layer of farm bunker silos through the use of a next-generation barrier film with high impermeability to oxygen. J. Dairy Sci. 97:2415-2426.

Burns, J. C., D. S. Fisher, and H. F. Mayland. 2007. Diurnal shifts in nutritive value of alfalfa harvested as hay and evaluated by animal intake and digestion. Crop Sci. 47:2190-2197.

Burns, J. C., H. F. Mayland, and D. S. Fisher. 2005. Dry matter intake and digestion of alfalfa harvested at sunset and sunrise. J. Anim. Sci. 83:262-270.

Buxton, D. R. 1996. Quality-related characteristics of forages as influenced by plant environment and agronomic factors. Anim. Feed Sci. Technol. 59:37-49.

Buxton, D. R., and S. L. Fales. 1994. Plant environment and quality. Pages 155-199 in Forage Quality, Evaluation and Utilization. G. C. Fahey Jr., M. Collins, D. R. Mertens, and L. E. Moser, ed. Am. Soc. Agron., Crop Sci. Soc. Am., Soil Sci. Soc. Am., Madison, WI.

Cairns, A. J., R. Nash, M.-A. M. de Carvalho, and I. M. Sims. 1999 Characterization of the enzymatic polymerization of 2,6-linked fructan by leaf extracts from timothy grass (Phleum pratense). New Phytol. 142:79-91.

Calder, F., W. J. E. Langille, and J. W. G. Nicholson. 1977. Feeding value for beef steers of corn silage as affected by harvest dates and frost. Can. J. Anim. Sci. 57:65-73.

Campos, A. F. 2015. Effect of particle size on ensilability and nutritive value of sugarcane silage for beef cattle. PhD Diss. São Paulo State University, Jaboticabal, Brazil. (In Portuguese.)

Cao, Y., Y. Cai, T. Hirakubo, H. Fukui, and H. Matsuyama. 2011. Fermentation characteristics and microorganism composition of total mixed ration silage with local food by-products in different seasons. Anim. Sci. J. 82:259-266.

Carvalho, B. F., C. L. S. Ávila, T. F. Bernardes, M. N. Pereira, C. Santos, and R. F. Schwan. 2017. Fermentation profile and identification of lactic acid bacteria and yeasts of rehydrated corn kernel silage. J. Appl. Microbiol. 122:589-600.

Carvalho, G. G. P., R. Garcia, A. J. V. Pires, J. A. G. Azevedo, F. E. P. Fernandes, and O. G. Pereira. 2007. Nutritive value and fermentation characteristics of elephant grass silages with addition of coffee hulls. Rev. Bras. Zootec. 36:1875-1881. (In Portuguese.)

Chamberlain, D. G. 1987. The silage fermentation in relation to the utilization of nutrients in the rumen. Process Biochem. 22:60-63.

Chatterton, N. J., P. A. Harrison, J. H. Bennett, and K. H. Asay. 1989. Carbohydrate partitioning in 185 accessions of Graminae grown under warm and cool temperatures. J. Plant Physiol. 134:169-174.

Choung, J.-J., and D. G. Chamberlain. 1993. Effects of addition of lactic acid and post-ruminal supplementation with casein on the 
nutritional value of grass silage for milk production in dairy cows. Grass Forage Sci. 48:380-386.

Cone, J. W., and F. M. Engels. 1990. Influence of growth temperature on anatomy and in vitro digestibility of maize tissues. J. Agric. Sci. $114: 207-212$

Correa, C. E. S., M. N. Pereira, S. G. Oliveira, and M. H. Ramos. 2003. Performance of Holstein cows fed sugarcane or corn silages of different grain texture. Sci. Agric. 60:621-629.

Costa, M. G., J. M. S. Campos, S. C. Valadares Filho, R. F. D. Valadares, S. S. Mendonça, D. P. Souza, and M. P. Teixeira. 2005. Effects of feeding corn silage or different dietary ratios of sugarcane and concentrate on production of lactating dairy cows. Rev. Bras. Zootec. 34:2437-2445. (In Portuguese.)

Crasta, O. R., and W. J. Cox. 1996. Temperature and soil water effects on maize growth, development yield, and forage quality. Crop Sci. $36: 341-348$.

D'Amours, L., and P. Savoie. 2005. Density profile of corn silage in bunker silos. Can. Biosyst. Eng. 47:2.21-2.28.

Da Silva, N. C., J. P. Dos Santos, C. L. S. Ávila, A. R. Evangelista, D. R. Casagrande, and T. F. Bernardes. 2014. Evaluation of the effects of two Lactobacillus buchneri strains and sodium benzoate on the characteristics of corn silage in a hot-climate environment. Grassl. Sci. 60:169-177.

Daniel, J. L. P., R. C. Amaral, A. Sá Neto, E. H. Cabezas-Garcia, A W. Bispo, M. Zopollatto, T. L. Cardoso, M. H. F. Spoto, F. A. P. Santos, and L. G. Nussio. 2013a. Performance of dairy cows fed high levels of acetic acid or ethanol. J. Dairy Sci. 96:398-406.

Daniel, J. L. P., A. Capelesso, E. H. Cabezas-Garcia, M. Zopollatto, M. C. Santos, P. Huhtanen, and L. G. Nussio. 2013b. Fibre digestion potential in sugarcane across the harvesting window. Grass Forage Sci. 69:176-181.

Daniel, J. L. P., F. A. Jacovaci, D. Junges, M. C. Santos, J. R. Lima, I. A. Anjos, M. G. A. Landell, P. Huhtanen, and L. G. Nussio. 2017. Fibre digestibility and its relationships with chemical and morphological traits in thirty-two sugarcane varieties. Grass Forage Sci. 72:545-555.

Daniel, J. L. P., D. Junges, and L. G. Nussio. 2015. A meta-analysis of the effects of length of storage on starch digestibility and aerobic stability of corn silages. Pages 306-307 in Proc. 17th Intl. Silage Conf., Piracicaba, Brazil. University of São Paulo, Piracicaba, Brazil.

Daniel, J. L. P., K. Weiß, L. Custódio, A. Sá Neto, M. C. Santos, M. Zopollatto, and L. G. Nussio. 2013c. Occurrence of volatile organic compounds in sugarcane silages. Anim. Feed Sci. Technol. 185:101-105.

De Oliveira, I. L., L. M. Lima, D. R. Casagrande, M. A. S. Lara, and T. F. Bernardes. 2017. Nutritive value of corn silage from intensive dairy farms in Brazil. Rev. Bras. Zootec. 46:494-501.

Deinum, B., J. Debeyer, P. H. Nordfeldt, A. Kornher, O. Ostgard, and G. Vanbogaert. 1981. Quality of herbage at different latitudes. Neth. J. Agric. Sci. 29:141-150.

Deinum, B., A. J. H. van Es, and P. J. van Soest. 1968. Climate, nitrogen, and grass. II. The influence of light intensity, temperature and nitrogen on in vivo digestibility of grass and the prediction of these effects from some chemical procedures. Neth. J. Agric. Sci. $16: 217-223$

Dos Passos Bernardes, A., G. F. Tremblay, G. Belanger, P. Seguin, A Bregard, and A. Vanasse. 2016. Bagasse silage from sweet pearl millet and sweet sorghum as influenced by harvest dates and delays between biomass chopping and pressing. Bioenerg. Res. 9:88-97.

Drapeau, R., G. Belanger, G. F. Tremblay, and R. Michaud. 2005 Rendement et valeur nutritive de la fétuque élevée cultivées en régions à faibles degrés-jours de croissance. Can. J. Plant Sci. 85:369-376.

Drapeau, R., G. Bélanger, G. F. Tremblay, and R. Michaud. 2007. Yield, persistence, and nutritive value of autumn-harvested tall fescue. Can. J. Plant Sci. 87:67-75.

Drapeau, R., G. F. Tremblay, G. Bélanger, and R. Michaud. 2002. Récoltes tardives du maïs fourrager en régions à faibles unités thermiques. Can. J. Plant Sci. 82:319-327.
Driehuis, F., S. J. W. H. Oude Elferink, and S. F. Spoelstra. 1999. Anaerobic lactic acid degradation during ensilage of whole crop maize inoculated with Lactobacillus buchneri inhibits yeast growth and improves aerobic stability. J. Appl. Microbiol. 87:583-594.

Duncan, R. R. 1980. Methiocarb as a bird repellent on ripening grain sorghum. Can. J. Plant Sci. 60:1129-1133.

Edmunds, B., H. Spiekers, K.-H. Südekum, H. Nussbaum, F. J. Schwarz, and R. Bennett. 2012. Effect of extent and rate of wilting on nitrogen components of grass silage. Grass Forage Sci. 69:140152.

Eisner, I., K.-H. Südekum, and S. Kirchhof. 2006. Beziehungen zwischen Fermentationscharakteristika von Silagen und der Futteraufnahme von Milchkühen. Übersicht. Tierernähr. 34:197-221.

Fernandes, J. 2014. Influence of genotype, maturity and length of storage on silage corn grain quality with high moisture. MS Thesis. University of São Paulo, Piracicaba, Brazil. (In Portuguese.)

Ferraretto, L. F., and R. D. Shaver. 2012. Meta-analysis: Impact of corn silage harvest practice on intake, digestion and milk production by dairy cows. Prof. Anim. Sci. 28:141-149.

Ferullo, J.-M., L.-P. Vézina, J. Rail, S. Laberge, P. Nadeau, and Y. Castonguay. 1997. Differential accumulation of two glycine-rich proteins during cold-acclimation alfalfa. Plant Mol. Biol. 33:625633.

Fisher, D. S., H. F. Mayland, and J. C. Burns. 1999. Variation in ruminants' preference for tall fescue hays cut either at sundown or at sunup. J. Anim. Sci. 77:762-768.

Fisher, D. S., H. F. Mayland, and J. C. Burns. 2002. Variation in ruminant preference for alfalfa hays cut at sunup and sundown. Crop Sci. 42:231-237.

Forristal, P. D., and P. O'Kiely. 2005. Update on technologies for producing and feeding silage. Pages 83-96 in Proc. 14th Int. Silage Conf., Dublin, Ireland. Wageningen Academic Publishers, Wageningen, the Netherlands.

Garcia, A. D., W. G. Olson, D. E. Otterby, J. G. Linn, and W. P. Hansen. 1989. Effects of temperature, moisture, and aeration on fermentation of alfalfa silage. J. Dairy Sci. 72:137-143.

Gerlach, K., F. Roß, K. Weiß, W. Büscher, and K. H. Südekum. 2013. Changes in maize silage fermentation products during aerobic deterioration and effects on dry matter intake by goats. Agric. Food Sci. $22: 168-181$

Gherardi, S. G., R. C. Kellaway, and J. L. Black. 1992. Effect of forage particle length on digesta load, packing density and voluntary feed intake by sheep. Aust. J. Agric. Res. 43:1321-1336.

Goering, H. K., P. J. Van Soest, and R. W. Hemken. 1973. Relative susceptibility of forages to heat damage as affected by moisture, temperature, and pH. J. Dairy Sci. 56:137-143.

Goulart, R., J. Daniel, V. Santos, R. Amaral, G. Muraro, S. Toledo Filho, L. Nussio, and A. Pires. 2009. Adjustment of physically effective fiber sources in diets for beef cattle. J. Dairy Sci. 92(ESuppl. 1):297. (Abstr.)

Gusmão, J. O., B. L. Ferraz, L. M. Lima, P. H. Couto, S. M. S. Silva J. R. S. Gersávio, I. L. De Oliveira, and T. F. Bernardes. 2017. Total mixed ration silage containing elephant grass as a forage source for low-producing dairy cattle. Page 727 in Proc. 54th Int. Animal Sci. Meeting, Foz do Iguaçu, Brazil. The Brazilian Society of Animal Science, Brasília, Brazil.

Ham, G. A., R. A. Stock, T. J. Klopfenstein, E. M. Larson, D. H Shain, and R. P. Huffman. 1994. Wet corn distillers byproducts compared with dried corn distillers grain with soluble as a source of protein and energy for ruminants. J. Anim. Sci. 72:3246-3257.

Han, K. J., M. Collins, E. S. Vanzant, and C. T. Dougherty. 2004. Bale density and moisture effects on alfalfa round bale silage. Crop Sci. 44:914-919.

Hardacre, A. K., and H. L. Turnbull. 1986. The growth and development of maize (Zea mays L.) at five temperatures. Ann. Bot. 58:779-787.

Harrison, J., P. Huhtanen, and M. Collins. 2003. Perennial grasses, Pages 665-747 in Silage Science and Technology. D. R. Buxton, R. E. Muck, and J. H. Harrison, ed. American Society of Agronomy, Madison, WI. 
Holmes, B. J. 2009. Software applications for sizing silos to maximize silage quality. Pages 189-208 in Proc. Intl. Symp. Forage Qual. Conserv., Piracicaba, Brazil. University of São Paulo, Piracicaba, Brazil.

Honig, H. 1991. Reducing losses during storage and unloading of silage. Pages 116-128 in Silage Conservation Towards 2000. Institute of Grassland and Forage Research and Federal Research Center of Agriculture Braunschweig-Volkenrode, Braunschweig, Germany.

Huhtanen, P., J. I. Nousiainen, H. Khalili, J. Jaakkola, and T. Heikkilä. 2003. Relationships between silage fermentation characteristics and milk production parameters: Analyses of literature data. Livest. Prod. Sci. 81:57-73.

Huhtanen, P., M. Rinne, and J. Nousiainen. 2007. Evaluation of the factors affecting silage intake of dairy cows; A revision of the relative silage dry matter intake index. Animal 1:758-770.

Jaakkola, S., and P. Huhtanen. 1992. Rumen fermentation and microbial protein synthesis in cattle given increasing levels of lactic acid with grass silage based diet. J. Agric. Sci. 119:411-419.

Jaakkola, S., V. Kaunisto, and P. Huhtanen. 2006. Volatile fatty acid proportions and microbial protein synthesis in the rumen of cattle receiving grass silage ensiled with different rates of formic acid. Grass Forage Sci. 61:282-292.

Jonsson, A., H. Lindberg, S. Sundås, P. Lingval, and S. Lindgren. 1990. Effect of additives on the quality of big-bale silage. Anim. Feed Sci. Technol. 31:139-155.

Keeling, P. L., R. Banisadr, L. Barone, B. P. Wasserman, and G. W. Singletary. 1994. Effect of temperature on enzymes in the pathway of starch biosynthesis in developing wheat and maize grain. Aust. J. Plant Physiol. 21:807-827.

Kim, S. C., and A. T. Adesogan. 2006. Influence of ensiling temperature, simulated rainfall, and delayed sealing on fermentation characteristics and aerobic stability of corn silage. J. Dairy Sci. 89:3122-3132.

Knicky, M., and R. Spörndly. 2009. Sodium benzoate, potassium sorbate and sodium nitrite as silage additives. J. Sci. Food Agric. 89:2659-2667.

Koc, F., L. Coskuntuna, M. L. Ozduven, A. Coskuntuna, and H. E. Samli. 2009. The effects of temperature on the silage microbiology and aerobic stability of corn and vetch-grain silages. Acta Agric. Scand. A 59:239-246.

Korosteleva, S. N., T. K. Smith, and H. J. Boermans. 2007. Effects of feedborne Fusarium mycotoxins on the performance, metabolism, and immunity of dairy cows. J. Dairy Sci. 90:3867-3873.

Lima, L. M., J. P. Dos Santos, D. R. Casagrande, C. L. S. Ávila, M. A. S. Lara, and T. F. Bernardes. 2017. Lining bunker walls with oxygen barrier film reduces nutrient losses in corn silages. J. Dairy Sci. 100:4565-4573.

Lingvall, P., and P. Lättemäe. 1999. Influence of hexamine and sodium nitrite in combination with sodium benzoate and sodium propionate on fermentation and hygienic quality of wilted and long cut grass silage. J. Sci. Food Agric. 79:257-264.

Liu, Q., J. Zhang, S. Shi, and Q. Sun. 2011. The effects of wilting and storage temperatures on the fermentation quality and aerobic stability of stylo silage. Anim. Sci. J. 82:549-553.

Lopes, J. C., R. D. Shaver, P. C. Hoffman, M. S. Akins, S. J. Bertics, H. Gencoglu, and J. G. Coors. 2009. Type of corn endosperm influences nutrient digestibility in lactating dairy cows. J. Dairy Sci. 92:4541-4548.

Ma, B. L., K. D. Subedi, D. W. Stewart, and L. M. Dwyer. 2006. Dry matter accumulation and silage moisture changes after silking in leafy and dual-purpose corn hybrids. Agron. J. 98:922-929.

Macken, C., G. Erickson, T. Milton, T. Klopfenstein, and H. Block. 2003. Effects of starch endosperm type and corn processing method on feedlot performance, nutrient digestibility, and ruminal fermentation of high-grain diets. Pages $32-34$ in Nebraska Beef Cattle Report MP80-A. University of Nebraska, Lincoln.

Mahanna, B., and L. E. Chase. 2003. Practical applications and solutions to silage problems. Pages $855-895$ in Silage Science and Technology. Vol. 42. D. R. Buxton, R. E. Muck, and J. H. Harrison, ed. Am. Soc. Agron., Crop Sci. Soc. Am., Soil Sci. Soc. Am., Madison, WI.
Mann, J. A., C. T. Kimber, and F. R. Miller. 1983. The origin and early cultivation of sorghums in Africa. Texas Agric. Exp. Stn. Bull. 1454. Texas Agricultural Experiment Station, Texas A\&M University System, College Station.

Mari, L. J., R. J. Schmidt, L. G. Nussio, C. M. Hallada, and L. Kung Jr.. 2009. Short communication: An evaluation of the effectiveness of Lactobacillus buchneri 40788 to alter fermentation and improve the aerobic stability of corn silage in farm silos. J. Dairy Sci. 92:1174-1176.

Martin, S., and K. Peel. 2013. Using grain and forage sorghum in dairy rations in an environment of limited water resources. Accessed Sep. 28, 2017. http://alfalfa.ucdavis.edu/+symposium/ proceedings/2013/13WAS-17_Martin_SorghumStarch.pdf.

Maziero, P., J. Jong, F. M. Mendes, A. R. Gonçalves, M. Eder, and C. Driemeier. 2013. Tissue-specific cell wall hydration in sugarcane stalks. J. Agric. Food Chem. 61:5841-5847.

McDonald, P., A. R. Henderson, and S. J. E. Heron. 1991. The Biochemistry of Silage. 2nd ed. Chalcombe, Lincoln, UK.

McEniry, J., P. O'Kiely, N. J. W. Clipson, P. D. Forristal, and E. M. Doyle. 2008. The microbiological and chemical composition of silage over the course of fermentation in round bales relative to that of silage made from unchopped and precision-chopped herbage in laboratory silos. Grass Forage Sci. 63:407-420.

Melick, D. R., and R. D. Seppelt. 1992. Loss of soluble carbohydrates and changes in freezing point of Antarctic bryophytes after leaching and repeated freeze-thaw cycles. Antarct. Sci. 4:399-404.

Merry, R. J., A. L. Winters, P. I. Thomas, M. Müller, and T. Müller. 1995. Degradation of fructans by epiphytic and inoculated lactic acid bacteria and by plant enzymes during ensilage of normal and sterile hybrid ryegrass. J. Appl. Microbiol. 79:583-591.

Mohammadzadeh, H., M. Khorvash, and G. R. Ghorbani. 2014. Shortand long-time effects of multispecies lactic acid bacteria inoculant on fermentation characteristics and aerobic stability of corn silages at different maturities and frost killed corn. J. Anim. Res. 42:371-379.

Mohammadzadeh, H., M. Khorvash, G. R. Ghorbani, and W. Z. Yang. 2012. Frosted corn silage with or without bacterial inoculants in dairy cattle ration. Livest. Sci. 145:153-159.

Moore, K. J., and H. J. G. Jung. 2001. Lignin and fiber digestion. J. Range Manage. 54:420-430.

Morin, C., G. Bélanger, G. F. Tremblay, A. Bertrand, Y. Castonguay, R. Drapeau, R. Michaud, R. Berthiaume, and G. Allard. 2011. Diurnal variations of nonstructural carbohydrates and nutritive value in alfalfa. Crop Sci. 51:1297-1306.

Morin, C., G. Belanger, G. F. Tremblay, A. Bertrand, Y. Castonguay, R. Drapeau, R. Michaud, R. Berthiaume, and G. Allard. 2012a. Short communication: Diurnal variations of nonstructural carbohydrates and nutritive value in timothy. Can. J. Plant Sci. 92:883-887.

Morin, C., G. F. Tremblay, G. Belanger, A. Bertrand, Y. Castonguay, R. Drapeau, R. Michaud, R. Berthiaume, and G. Allard. 2012b. Nonstructural carbohydrate concentration during field wilting of PM- and AM-cut alfalfa. Agron. J. 104:649-660.

Muchow, R. C., T. R. Sinclair, and J. M. Bennett. 1990. Temperature and solar radiation effects on potential maize yield across locations. Agron. J. 82:338-343.

Muck, R. E., and B. J. Holmes. 2000. Factors affecting bunker silo densities. Appl. Eng. Agric. 16:613-619.

Muck, R. E., L. E. Moser, and R. E. Pitt. 2003. Postharvest factors affecting ensiling. Pages 251-304 in Silage Science and Technology. Vol. 42. D. R. Buxton, R. E. Muck, and J. H. Harrison, ed. Am. Soc. Agron., Crop Sci. Soc. Am., Soil Sci. Soc. Am., Madison, WI..

Muck, R. E., and K. J. Shinners. 2001. Conserved forage (silage and hay): Progress and priorities. Pages 753-762 in Proc. 19th Intl. Grassl. Congr., São Pedro, Brazil. University of São Paulo, Piracicaba, Brazil.

Nsereko, V. L., and J. A. Rooke. 2000. Characterisation of peptides in silages made from perennial ryegrass with different silage additives. J. Sci. Food Agric. 80:725-731. 
Nussio, L. G. 2005. Silage production from tropical forages. Pages 97-107 in Proc. 14th Intl. Silage Conf., Belfast, UK. Wageningen Academic Publishers, Wageningen, the Netherlands.

O'Brien, M., P. O'Kiely, P. D. Forristal, and H. T. Fuller. 2007. Quantification and identification of fungal propagules in well-managed baled grass silage and in normal on-farm produced bales. Anim. Feed Sci. Technol. 132:283-297.

Ogunade, I. M., K. G. Arriola, Y. Jiang, J. P. Driver, C. R. Staples, and A. T. Adesogan. 2016. Effects of 3 sequestering agents on milk aflatoxin M1 concentration and the performance and immune status of dairy cows fed diets artificially contaminated with aflatoxin B1. J. Dairy Sci. 99:6263-6273.

Oldham, J. D. 1984. Protein-energy interrelationships in dairy cattle. J. Dairy Sci. 67:1090-1114.

Oliveira, A. S., E. Detmann, J. M. S. Campos, D. S. Pina, S. M. Souza, and M. G. Costa. 2011. Meta-analysis of the impact of neutral detergent fiber on intake, digestibility and performance of lactating dairy cows. Rev. Bras. Zootec. 40:1587-1595. (In Portuguese.)

Ouellet, C. E. 1976. Winter hardiness and survival of forage crops in Canada. Can. J. Plant Sci. 56:679-689.

Ould-Ahmed, M., M.-L. Decau, A. Bertrand, M.-P. Prud'homme, C. Lafreniere, and P. Drouin. 2015. Fructan, sucrose and related enzyme activities are preserved in timothy (Phleum pratense L.) during wilting. Grass Forage Sci. 72:64-79.

Ould-Ahmed, M., M. L. Decau, A. Morvan-Bertrand, M.-P. Prud'homme, C. Lafreniere, and P. Drouin. 2014. Plant maturity and nitrogen fertilization affected fructan metabolism in harvestable tissues of timothy (Phleum pratense L.). J. Plant Physiol. 171:1479-1490.

Owens, F. 2008. Corn silage - Facts, fantasies, and the future. Accessed Jan. 23, 2017. http://dairy.ifas.ufl.edu/rns/2008/Owens.pdf.

Paillat, J. M., and F. Gaillard. 2001. Air-tightness of wrapped bales and resistance of polythene stretch film under tropical and temperate conditions. J. Agric. Eng. Res. 79:15-22.

Papadopoulos, Y. A., and B. D. McKersie. 1983. A comparison of protein degradation during wilting and ensiling of six forage species. Can. J. Plant Sci. 63:903-912.

Pedroso, A. F., L. G. Nussio, D. R. S. Loures, S. F. Paziani, J. L. Ribeiro, L. J. Mari, M. Zopollatto, P. Schmidt, W. R. S. Mattos, and J. Horii. 2008. Fermentation, losses, and aerobic stability of sugarcane silages treated with chemical or bacterial additives. Sci. Agric. 65:589-594.

Pelletier, S., G. F. Tremblay, G. Bélanger, A. Bertrand, Y. Castonguay, D. Pageau, and R. Drapeau. 2010. Forage nonstructural carbohydrates and nutritive value as affected by time of cutting and species. Agron. J. 102:1388-1398.

Pelletier, S., G. F. Tremblay, C. Lafrenière, A. Bertrand, G. Bélanger, Y. Castonguay, and J. Rowsell. 2009. Nonstructural carbohydrate concentrations in timothy as affected by $\mathrm{N}$ fertilization, stage of development, and time of cutting. Agron. J. 101:1372-1380.

Pholsen, S., W. Khota, H. Pang, D. Higgs, and Y. Cai. 2016. Characterization and application of lactic acid bacteria for tropical silage preparation. Anim. Sci. J. 87:1202-1211.

Pino, F., and A. J. Heinrichs. 2017. Sorghum forage in precision-fed dairy heifer diets. J. Dairy Sci. 100:224-235.

Pitt, R. E., and R. E. Muck. 1993. A diffusion model of aerobic deterioration at the exposed face of bunker silos. J. Agric. Eng. Res. $55: 11-26$

Queiroz, O. C. M., A. T. Adesogan, K. G. Arriola, and M. F. S. Queiroz. 2012. Effect of a dual-purpose inoculant on the quality and nutrient losses from corn silage produced in farm-scale silos. J. Dairy Sci. 95:3354-3362.

Queiroz, O. C. M., K. G. Arriola, J. L. P. Daniel, and A. T. Adesogan. 2013. Effects of 8 chemical and bacterial additives on the quality of corn silage. J. Dairy Sci. 96:5836-5843.

Queiroz, O. C. M., L. G. Nussio, P. Schmidt, J. L. Ribeiro, M. C. Santos, and M. Zopollatto. 2008. Sugarcane silage as compared to traditional supplemental sources of forage in the performance of high production cows. Rev. Bras. Zootec. 37:358-365. (In Portuguese.)
Randby, Å. T., I. Selmer-Olsen, and L. Baevre. 1999. Effect of ethanol in feed on milk flavor and chemical composition. J. Dairy Sci. $82: 420-428$

Raun, B. M. L., and N. B. Kristensen. 2011. Metabolic effects of feeding ethanol or propanol to postpartum transition Holstein cows. J. Dairy Sci. 94:2566-2580.

Sá Neto, A., A. W. Bispo, D. Junges, A. K. Bercht, M. Zopollatto, J. L. P. Daniel, and L. G. Nussio. 2014. Exchanging physically effective neutral detergent fiber does not affect chewing activity and performance of late-lactation dairy cows fed corn and sugarcane silages. J. Dairy Sci. 97:7012-7020.

Sanaullah, M., A. Chabbi, G. Lemaire, X. Charrier, and C. Rumpel. 2010. How does plant leaf senescence of grassland species influence decomposition kinetics and litter compounds dynamics? Nutr. Cycl. Agroecosyst. 88:159-171.

Santos, V. P. 2010. Particle size of fresh sugarcane fed to lactating cows and goats. PhD Diss. University of São Paulo, Piracicaba, Brazil. (In Portuguese.)

Saue, O., and K. Breirem. 1969. Formic acid as a silage additive. Pages 161-172 in Proc. 3rd Gen. Meeting of European Grassland Federation, Braunschweig, Germany. Deutsche Landwirtschaftsgesellschaft, Frankfurt am Maine, Germany.

Schlenker, W., and M. J. Roberts. 2006. Nonlinear effects of weather on corn yields. Rev. Agric. Econ. 28:391-398.

Schlenker, W., and M. J. Roberts. 2009. Nonlinear temperature effects indicate severe damages to U.S. crop yields under climate change. Proc. Natl. Acad. Sci. USA 106:15594-15598.

Slottner, D., and J. Bertilsson. 2006. Effect of ensiling technology on protein degradation during ensilage. Anim. Feed Sci. Technol. 127:101-111.

Snell, H. G. J., C. Oberndorfer, W. Lucke, and H. F. A. Van den Weghe. 2003. Effects of polyethylene colour and thickness on grass silage quality. Grass Forage Sci. 58:239-248.

St Pierre, N. R., R. Bouchard, G. St-Laurent, G. L. Roy, and C. Vinet. 1987. Performance of lactating dairy cows fed silage from corn of varying maturities. J. Dairy Sci. 70:108-115.

Struik, P. C. 1983. The effects of short and long shading, applied during different stages of growth, on the development, productivity and quality of forage maize (Zea mays L.). Neth. J. Agric. Sci. $31: 101-124$

Thorsteinsson, B., P. A. Harrison, and N. J. Chatterton. 2002. Fructan and total carbohydrate accumulation in leaves of two cultivars of timothy (Phleum pratense Vega and Climax) as affected by temperature. J. Plant Physiol. 159:999-1003.

Thorvaldsson, G., G. F. Tremblay, and H. T. Kunelius, 2007. The effects of growth temperature on digestibility and fibre concentration of seven temperate grass species. Acta Agric. Scand. B $57: 322-328$

Tremblay, G. F., G. Belanger, and R. Drapeau. 2005. Nitrogen fertilizer application and developmental stage affect silage quality of timothy (Phleum pratense L.). Grass Forage Sci. 60:337-355.

Tremblay, G. F., C. Morin, G. Belanger, A. Bertrand, Y. Castonguay, R. Berthiaume, and G. Allard. 2014. Silage fermentation of PMand AM-cut alfalfa wilted in wide and narrow swaths. Crop Sci. $54: 439-452$.

Van den Ende, W., B. De Coninck, and A. Van Laere. 2004. Plant fructan exohydrolases: A role in signaling and defense? Trends Plant Sci. 9:523-528.

Van Ranst, G., M. Vandewalle, F. Gadeyne, J. De Riek, and V. Fievez. 2013. Lipid metabolism in mixtures of red clover (Trifolium repens) and perennial ryegrass (Lolium perenne) in lab scale silages and in vitro rumen incubations. Animal 7:1454-1463.

Virtanen, A. I. 1933. The A.I.V. method of preserving fresh fodder. Emp. J. Exp. Agric. 1:143-155.

Vissers, M. M. M., F. Driehuis, M. C. te Giffel, P. De Jong, and J. M. G. Lankveld. 2007. Concentrations of butyric acid bacteria spores in silage and relationships with aerobic deterioration. J. Dairy Sci 90:928-936.

Wang, C., and N. Nishino. 2013. Effects of storage temperature and ensiling period on fermentation products, aerobic stability and mi- 
crobial communities of total mixed ration silage. J. Appl. Microbiol. 114:1687-1695.

Wang, P., C. S. Bai, L. Liu, and B. H. Cao. 2011. Effects of lactic acid bacteria inoculant on the fermentation quality of reed grass (Phragmites australis Cav. Trin. ex Sterd.) at low temperature. Acta Agrestia Sinica. 19:127-131.

Weinberg, Z. G., and R. E. Muck. 1996. New trends and opportunities in the development and use of inoculants for silage. FEMS Microbiol. Rev. 19:53-68.

Weinberg, Z. G., G. Szakacs, G. Ashbell, and Y. Hen. 2001. The effect of temperature on the ensiling process of corn and wheat. J. Appl. Microbiol. 90:561-566.

Weiss, K., B. Kroschewski, and H. Auerbach. 2016. Effects of air exposure, temperature and additives on fermentation characteristics, yeast count, aerobic stability and volatile organic compounds in corn silage. J. Dairy Sci. 99:8053-8069.

White, R. P., K. A. Winter, and H. T. Kunelius. 1976. Yield and quality of silage corn as affected by frost and harvest date. Can. J. Plant Sci. 56:481-486.

Wilkins, R., and M. Wilkinson. 2015. Major contributions in 45 years of International Silage Conferences. Pages 26-51 in Proc. XVII Intl. Silage Conf., Piracicaba, Brazil. University of São Paulo, Piracicaba, Brazil.

Wilkinson, J. M., K. K. Bolsen, and C. J. Lin. 2003. History of silage. Pages 1-30 in Silage Science and Technology. Vol. 42. D. R. Buxton, R. E. Muck, and J. H. Harrison, ed. Am. Soc. Agron., Crop Sci. Soc. Am., Soil Sci. Soc. Am., Madison, WI.
Wilman, D. 2004. Some changes in grass crops during periods of uninterrupted growth. J. Agric. Sci. 142:129-140.

Wilson, J. R. 1993. Organization of forage plant tissues. Pages 1-32 in Forage Cell Wall Structure and Digestibility. H. G. Jung, D. R. Buxton, R. D. Hatfield, and J. Ralph, ed. Am. Soc. Agron., Crop Sci. Soc. Am., Soil Sci. Soc. Am., Madison. WI.

Wilson, J. R., B. Deinum, and F. M. Engels. 1991. Temperature effects on anatomy and digestibility of leaf and stem of tropical and temperate forage species. Neth. J. Agric. Sci. 39:3-48.

Winters, A. L., R. J. Merry, M. Müller, D. R. Davies, G. Pahlow, and T. Müller. 1998. Degradation of fructans by epiphytic and inoculant lactic acid bacteria during ensilage of grass. J. Appl. Microbiol. 84:304-312.

Woolford, M. K. 1990. The detrimental effect of air on silage. J. Appl. Bacteriol. 68:101-116.

Zhang, M., H. Lv, Z. Tan, Y. Li, Y. Wang, H. Pang, Z. Li, Z. Jiao, and Q. Jin. 2017. Improving the fermentation quality of wheat straw silage stored at low temperature by psychrotrophic lactic acid bacteria. Anim. Sci. J. 88:277-285.

Zhou, Y., P. Drouin, and C. Lafreniere. 2016. Effect of temperature $\left(5-25^{\circ} \mathrm{C}\right)$ on epiphytic lactic acid bacteria populations and fermentation of whole-plant corn silage. J. Appl. Microbiol. 121:657-671.

Zopollato, M., and J. O. Sarturi. 2009. Optimization of the animal production system based on the selection of corn cultivars for silage. Pages 73-90 in Proc. Intl. Symp. Forage Qual. Conserv., São Pedro, Brazil. University of São Paulo, Piracicaba, Brazil. 